\title{
Review
}

\section{The Function of the Mutant p53-R175H in Cancer}

\author{
Yen-Ting Chiang ${ }^{1}$, Yi-Chung Chien ${ }^{1,2,3,4,5}$, Yu-Heng Lin ${ }^{1}$, Hui-Hsuan Wu ${ }^{1}$, Dung-Fang Lee ${ }^{6,7,8,9, *(D)}$ \\ and Yung-Luen Yu 1,2,3,4,5,10,*iD
}

1 Graduate Institute of Biomedical Sciences, China Medical University, Taichung 40402, Taiwan; u104001403@cmu.edu.tw (Y.-T.C.); chenyc0710@mail.cmu.edu.tw (Y.-C.C.); u109210209@cmu.edu.tw (Y.-H.L.); u108210214@cmu.edu.tw (H.-H.W.)

2 Program for Translational Medicine, China Medical University, Taichung 40402, Taiwan

3 Institute of New Drug Development, China Medical University, Taichung 40402, Taiwan

4 Drug Development Center, Research Center for Cancer Biology, China Medical University, Taichung 40402, Taiwan

5 Center for Molecular Medicine, China Medical University Hospital, Taichung 40402, Taiwan

6 Department of Integrative Biology and Pharmacology, McGovern Medical School, The University of Texas Health Science Center at Houston, Houston, TX 77030, USA

7 UTHealth Graduate School of Biomedical Sciences, The University of Texas MD Anderson Cancer Center, Houston, TX 77030, USA

8 Center for Stem Cell and Regenerative Medicine, The Brown Foundation Institute of Molecular Medicine for the Prevention of Human Diseases, The University of Texas Health Science Center at Houston, Houston, TX 77030, USA

9 Center for Precision Health, School of Biomedical Informatics and School of Public Health, The University of Texas Health Science Center at Houston, Houston, TX 77030, USA

10 Department of Medical Laboratory Science and Biotechnology, Asia University, Taichung 41354, Taiwan

* Correspondence: dung-fang.lee@uth.tmc.edu (D.-F.L.); ylyu@mail.cmu.edu.tw (Y.-L.Y.)

check for

updates

Citation: Chiang, Y.-T.; Chien, Y.-C.; Lin, Y.-H.; Wu, H.-H.; Lee, D.-F.; Yu, Y.-L. The Function of the Mutant p53-R175H in Cancer. Cancers 2021, 13, 4088. https://doi.org/10.3390/ cancers13164088

Academic Editor: Alfonso Baldi

Received: 16 June 2021

Accepted: 11 August 2021

Published: 13 August 2021

Publisher's Note: MDPI stays neutral with regard to jurisdictional claims in published maps and institutional affiliations.

Copyright: (c) 2021 by the authors. Licensee MDPI, Basel, Switzerland. This article is an open access article distributed under the terms and conditions of the Creative Commons Attribution (CC BY) license (https:// creativecommons.org/licenses/by/ $4.0 /)$.
Simple Summary: TP53 is one of the most well-known and intensively studied tumor-suppressor genes. TP53 is also the most commonly mutated gene in cancer. Many TP53 mutations are missense mutations and are located in several hotspots. Increasing evidence has shown that these hotspot mutations both lose the wild-type function and gain oncogenic functions to promote cancer progression. Among these hotspot mutations, p53-R175H has the highest occurrence in diverse cancers. In this review, we summarize studies associated with p53-R175H gain of function, and outline the current situation of the development of small molecules or immunotherapies that target p53-R175H.

Abstract: Wild-type p53 is known as "the guardian of the genome" because of its function of inducing DNA repair, cell-cycle arrest, and apoptosis, preventing the accumulation of gene mutations. TP53 is highly mutated in cancer cells and most TP53 hotspot mutations are missense mutations. Mutant p53 proteins, encoded by these hotspot mutations, lose canonical wild-type p53 functions and gain functions that promote cancer development, including promoting cancer cell proliferation, migration, invasion, initiation, metabolic reprogramming, angiogenesis, and conferring drug resistance to cancer cells. Among these hotspot mutations, p53-R175H has the highest occurrence. Although losing the transactivating function of the wild-type p53 and prone to aggregation, p53-R175H gains oncogenic functions by interacting with many proteins. In this review, we summarize the gain of functions of p53-R175H in different cancer types, the interacting proteins of p53- $175 \mathrm{H}$, and the downstream signaling pathways affected by $\mathrm{p} 53-\mathrm{R} 175 \mathrm{H}$ to depict a comprehensive role of $\mathrm{p} 53-\mathrm{R} 175 \mathrm{H}$ in cancer development. We also summarize treatments that target p53- $175 \mathrm{H}$, including reactivating p53$\mathrm{R} 175 \mathrm{H}$ with small molecules that can bind to $\mathrm{p} 53-\mathrm{R} 175 \mathrm{H}$ and alter it into a wild-type-like structure, promoting the degradation of $\mathrm{p} 53-\mathrm{R} 175 \mathrm{H}$ by targeting heat-shock proteins that maintain the stability of $\mathrm{p} 53-\mathrm{R} 175 \mathrm{H}$, and developing immunotherapies that target the p53-R175H-HLA complex presented by tumor cells.

Keywords: mutant p53; p53 R175H; gain-of-function; targeted therapy; immunotherapy; cancer 


\section{Introduction}

Cancer is a set of diseases characterized by abnormal cell growth with the potential to invade other parts of the body. Douglas Hanahan and Robert A. Weinberg proposed six hallmarks of cancer: sustaining proliferative signaling, evading growth suppressors, resisting cell death, enabling replicative immortality, inducing angiogenesis, and activating invasion and metastasis [1]. These hallmarks can be acquired by mutations of genes that are involved in these biological processes. p53, a sequence-transcription factor encoded by the TP53 gene, is called "the guardian of the genome" because it can sense DNA damage in cells and turn on its downstream signaling that can induce DNA repair, cell-cycle arrest, and apoptosis by modulating the expression of its target genes. Once the p53 pathway has been altered, genetically damaged cells will not go into senescence or apoptosis, causing the accumulation of mutations and acquiring hallmarks of cancer [2]. The p53 protein has an $\mathrm{N}$-terminus containing transactivation domains, a DNA binding domain that binds to specific DNA sequences, and a C-terminus oligomerization and regulatory domains [3]. In data from The Cancer Genome Atlas (TCGA) program, $41.8 \%$ of cancer patients have alterations in TP53, suggesting that TP53 is highly mutated in cancer patients. Most TP53 mutations are located within the DNA binding domain (96-293 aa) and at several hotspots, such as R175, R248, R273, and R282 (Figure 1a). The pattern of TP53 hotspots distribution from the International Agency for Research on Cancer (IARC) TP53 somatic mutation database is similar to the TCGA database. R175, G245, R248, R249, R273, and R282 are the top six frequently mutated sites (Figure 1b). As for the IARC TP53 germline mutation database, the distribution of hotspots is similar to the somatic database, except for the high mutation frequency in R337 (Figure 1c) [4,5]. TP53-R337H, also known as "the Brazilian germline TP53 mutation", increases predisposition to childhood adrenocortical tumor, while the detailed molecular mechanism needs further investigation [6]. There might be several reasons that could explain why there are hotspot mutations in the TP53 gene. First, different mutations might have different levels of impact on the function of p53, either by altering the global protein structure or disrupting the p53-DNA interface, and there is a selection for cancer cells that express p53 mutants, losing its wild-type function [7]. On the basis of the crystal structure of the p53-DNA complex [8], hotspots R248 and R273 come into direct contact with DNA, whereas R249 and R282 lie near the DNA contacting interface. The R175 hotspot is located at the zinc-binding site near the DNA binding interface, which is very important to the maintenance of structural stability. Therefore, the p53-R175H mutation causes a change in the protein structure. Based on the crystal structure, these hotspots can be classified as contact mutants (R248 and R273) which make direct contact with DNA and structural mutants (R175, G245, R249, and R282) which maintain the structure of the DNA binding interface [8]. Second, the occurrence of $C$ to $T$ transitions increased 10-fold in the $5^{\prime}$ methylated cytosine of CpG codons. Four of the six codons encoding arginine have $\mathrm{CpG}$ dinucleotides in the first two positions, which can explain why the top six most frequent missense mutations all occur at the arginine residue [9]. Lastly, missense mutations located at these hotspots encode mutant p53 oncoproteins that lose canonical tumor-suppressor functions and gain oncogenic functions to promote cancer progression. Among these hotspot mutations, p53-R175H has the highest occurrence in cancer patients in both the TCGA database and IARC TP53 somatic mutations database (Table 1). The p53- $\mathrm{R} 175 \mathrm{H}$ loses the transactivating function of the wild-type p53 due to its defective DNA binding interface. However, p53-R175H gains function by many kinds of mechanisms. It is reported that p53-R175H can bind to some DNA sequences which are different from the wild-type p53 response element and transactivate its target genes [10]. p53- $\mathrm{R} 175 \mathrm{H}$ can also interact with numerous kinds of transcription factors to enhance or suppress the expression of their target genes [11]. In addition, the p53-R175H is more prone to aggregation than the wild-type p53 because it exhibits a larger hydrophobic surface area and higher loop flexibility than the wild-type p53 [12]. p53-R175H aggregates can not only induce coaggregation of wild-type p53 to cause the loss of function but also induce coaggregation of p63 and p73 to cause gain-of-functions [13]. Different p53 mutants may 
gain different functions. In this review, we focus on the gain-of-function of p53-R175H and discuss its role in cancer development. In the last section, we summarize the current development of mutant-p53-targeted therapies.

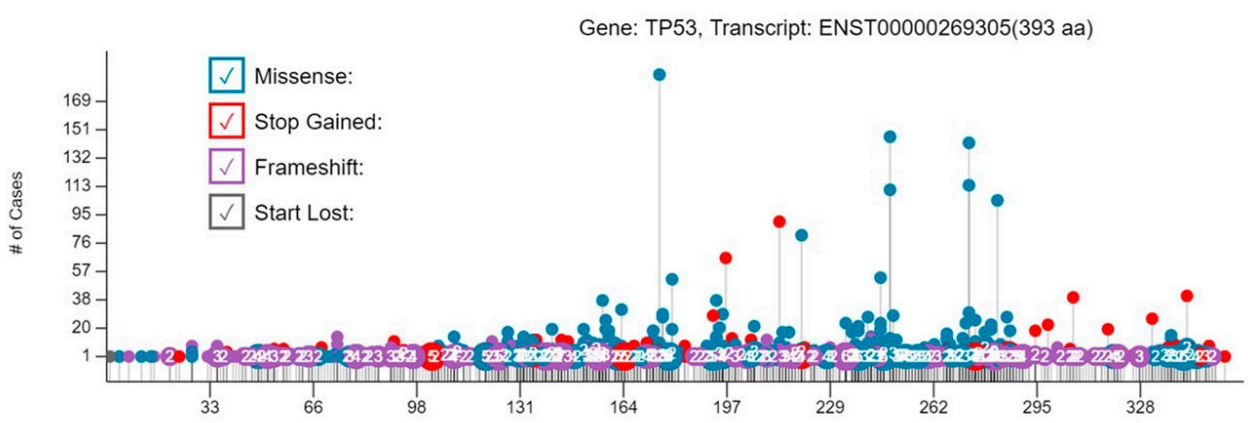

(a)

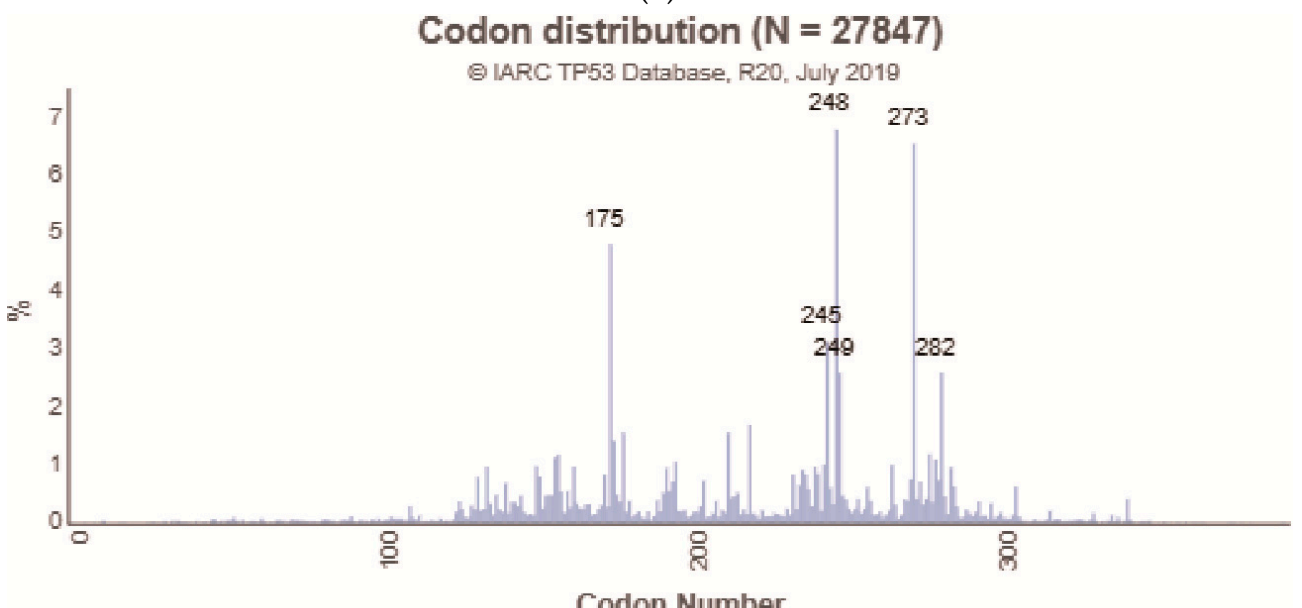

(b)

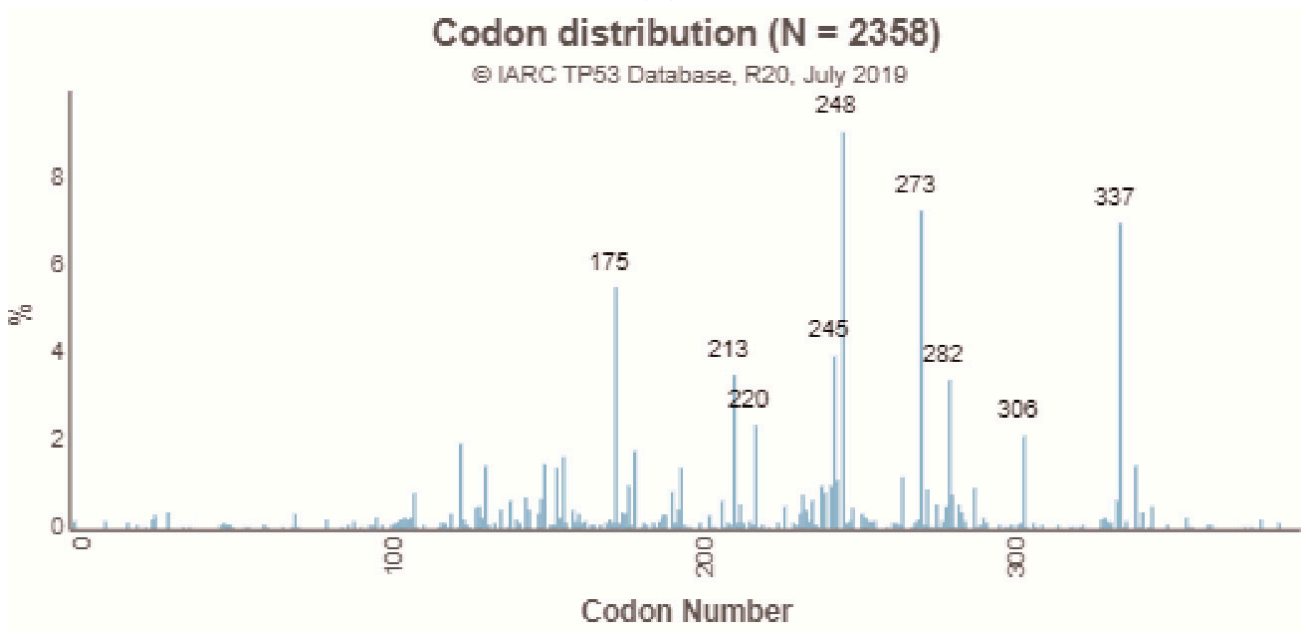

(c)

Figure 1. Distribution of TP53 mutations. (a) Distribution of TP53 mutations from the TCGA database. Picture obtained from National Cancer Institute GDC Data Portal; (b) Distribution of TP53 somatic mutations from the IARC TP53 database; (c) Distribution of TP53 germline mutations from the IARC TP53 database; and (b,c) Picture obtained from the IARC TP53 database website (https:/ / p53.iarc.fr / (accessed on 1 July 2021)). 
Table 1. Top 10 frequently occurring TP53 mutants. Data were obtained from the TCGA database and the IARC TP53 somatic mutations database.

\begin{tabular}{cccc}
\hline \multicolumn{2}{c}{ TCGA Database } & \multicolumn{2}{c}{$\begin{array}{c}\text { IARC TP53 Somatic } \\
\text { Mutations Database }\end{array}$} \\
\hline Mutants & $\begin{array}{c}\text { Percentage in TP53 Mutant } \\
\text { Cases }\end{array}$ & Mutants & $\begin{array}{c}\text { Percentage in TP53 } \\
\text { Mutant Cases }\end{array}$ \\
\hline Missense TP53 R175H & $3.69 \%$ & Missense R175H & $4.21 \%$ \\
Missense TP53 R248Q & $2.88 \%$ & Missense R248Q & $3.28 \%$ \\
Missense TP53 R273C & $2.80 \%$ & Missense R273H & $2.97 \%$ \\
Missense TP53 R273H & $2.25 \%$ & Missense R248W & $2.65 \%$ \\
Missense TP53 R248W & $2.19 \%$ & Missense R273C & $2.45 \%$ \\
Missense TP53 R282W & $2.05 \%$ & Missense R282W & $2.10 \%$ \\
Stop Gained TP53 R213 & $1.78 \%$ & Missense G245S & $1.58 \%$ \\
Missense TP53 Y220C & $1.60 \%$ & Missense R249S & $1.52 \%$ \\
Stop Gained TP53 R196 * & $1.30 \%$ & Missense Y220C & $1.39 \%$ \\
Missense TP53 G245S & $1.05 \%$ & Stop Gained TP53 R213 $1 *$ & $1.14 \%$ \\
\hline
\end{tabular}

\section{Gain-of-Function of Mutant $p 53-R 175 H$}

A large part of TP53 mutations in cancer cells is missense mutations which encode altered proteins, suggesting that these altered proteins may contribute some functions and are not just the result of loss of function mutations. In 1993, Dittmer et al. reported that mutant p53 proteins (V143A, R175H, R248W, R273H, and D281G) expressed in murine fibroblast cell lines ((10)3 cells) lacking p53 resulted in enhanced tumorigenic potential in nude mice. Mutant p53 alleles can also enhance the plating efficiency of the human osteosarcoma cell lines SAOS-2 and enhance the expression of the CAT gene in (10)3 cells [14]. In 2004, Olive et al. reported that $\mathrm{p} 53^{\mathrm{R} 172 \mathrm{H} /-}$ (mouse $\mathrm{R} 172 \mathrm{H}$ refers to human $\mathrm{R} 175 \mathrm{H}$ ) and $\mathrm{p} 53^{\mathrm{R} 270 \mathrm{H} /-}$ (mouse $\mathrm{R} 270 \mathrm{H}$ refers to human $\mathrm{R} 273 \mathrm{H}$ ) mice developed novel tumors compared to $\mathrm{p} 53^{-/-}$ mice, including a variety of carcinomas and more frequent endothelial tumors [15]. These two studies provided strong evidence to the mutant p53 gain-of-function hypothesis. In the last two decades, more and more studies have shown that p53 gain-of-function plays important role in tumorigenesis, and the mechanism has been investigated. Mutant p53 can modulate the expression of some genes by binding to their promotor with or without the help of different transcription factors, turning on many downstream oncogenic pathways. Mutant p53 can also bind to some enzymes to gain new functions. In this chapter, we summarize the $\mathrm{p} 53-\mathrm{R} 175 \mathrm{H}$ interacting proteins, target genes, and gain-of-function. We also list other p53 mutants that have gain-of-function the same as p53- $\mathrm{R} 175 \mathrm{H}$ in each study to make it easy to find which p53 mutants have phenotypes similar to p53-R175H or which molecular mechanisms are p53-R175H specific.

\subsection{Inducing Genetic Instability}

Acquisition of the multiple cancer hallmarks depends on a succession of alterations in the genomes of neoplastic cells [1]. TP53 is the central of the genomic integrity maintaining system because it can sense stress signals and force genetically damaged cells into either senescence or apoptosis [2]. However, it was reported that p53-R175H gains the function of inducing genetic instability. Hingorani et al. generated mouse pancreatic ductal adenocarcinoma model containing $\operatorname{Tr} p 53^{R 172 \mathrm{H}}$ and $\mathrm{Kras}{ }^{\mathrm{G} 12 \mathrm{D}}$. They found that the pancreatic carcinoma cells from mice expressing $T r p 53^{R 172 H}$ frequently contain greater than two centrosomes while the pancreatic carcinoma cells from Trp 53 wild-type mice have a normal number of centrosomes [16]. Liu et al. further identified that p53-R175H mice are cancer prone and in mouse embryonic fibroblast p53-R175H impairs the recruitment of MRN/ATM to DNA double strain break sites by interacting with MRN complex component Mre11, thereby inducing chromosomal translocation [17] (Table 2). 
Table 2. Summary of p53-R175H gain-of-function of inducing genetic instability.

\begin{tabular}{|c|c|c|c|c|}
\hline Tumor Type & $\begin{array}{l}\text { Same Function } \\
\text { Mutations }\end{array}$ & $\begin{array}{c}\mathrm{R} 175 \mathrm{~h} \\
\text { Interacting Protein }\end{array}$ & $\begin{array}{l}\text { Affected Downstream } \\
\text { Molecule or Pathway }\end{array}$ & Ref. \\
\hline Pancreatic cancer & - & - & - & [16] \\
\hline $\begin{array}{c}\text { None (mouse } \\
\text { embryonic fibroblast) }\end{array}$ & R248W, R273H & Mre11 & MRN/ATM & [17] \\
\hline
\end{tabular}

\subsection{Promoting Tumor Cell Growth}

Since the TP53 mutation often occurs in several hotspots by single nucleotide substitution resulting in missense mutation, scientists considered whether these mutant $p 53$ proteins both lose the wild-type p53 function and gain some unique functions to promote cancer-cell growth. In 2004, Scian et al. expressed hotspot mutants p53-R175H, p53-R273H, and p53-D281G in H1299, which is a p53 null human non-small-cell lung carcinoma cell line, and found that the proliferation rate of these cells increased compared to that of control cells. They also found that some growth-related genes, which are not the target genes of wild-type p53, are upregulated by these p53 mutants. However, they did not investigate the detailed mechanism [18]. GEF-H1, a guanine exchange factor-H1 for RhoA, was proved to be a p53-R175H, p53-V157F, and p53-R248Q target gene. The growth of many kinds of mutant p53 cancer cell lines but not the wild-type p53 cell lines is dependent on the expression of GEF-H1 [19]. Growth-regulated oncogene 1 (GRO1 or CXCL1) was reported to be another $\mathrm{p} 53-\mathrm{R} 175 \mathrm{H}$ target gene. $\mathrm{p} 53-\mathrm{R} 175 \mathrm{H}$ can transactivate the GRO1 gene by directly binding to its promoter region. Knockdown of GRO1 in colon adenocarcinoma cell line SW480 and pancreatic ductal adenocarcinoma cell line MIA PaCa-2 decreases cell viability [20]. In 2015, Zhu et al. reported a novel mutant $p 53$ gain-of-function mechanism that is associated with the chromatin pathway [21]. p53 with hotspot mutation can transcriptionally upregulate chromatin regulatory genes, including methyltransferases MLL1 (KMT2A), MLL2 (KMT2D), and acetyltransferase MOZ (KAT6A) by binding to their promoter regions together with ETS2, which is an ETS family transcription factor. Upregulation of these methyltransferases and acetyltransferase results in global increases in histone methylation and acetylation, and alters the expression of many genes that are essential to tumor growth. TCGA database analysis also revealed that, in many cancer types, MLL1, MLL2, and MOZ gene expression are upregulated in tumors with p53 hotspot mutation (R175H, R248Q, R248W, R249S, and R273H) compared to tumors with wild-type p53 [21]. This finding underscored that mutant p53 can alter the whole transcriptome by regulating epigenetic gene expression. In breast-cancer cell lines, mutant p53s can also bind to transcription factor NF-Y and cofactor YAP, and together activate several genes associated with cell growth, including cyclin $A$, cyclin $B$, and $C D K 1$ genes [22]. Additionally, p53-R175H and p53-R273H can cooperate with transcription factor MYB and transactivate replication-initiation-related genes $C D C 7$ and $D B F 4$. High $C D C 7$ expression correlates with mutant $p 53$ expression and poor prognosis in lung-adenocarcinoma patients [23]. Furthermore, Valentino et al. found that, in breast and prostate cancers, p53- $\mathrm{R} 175 \mathrm{H}$ and p53-R280K can induce PI3K/AKT signaling pathway and promote tumor growth by binding to tumor suppressor DAB2IP. DAB2IP can directly bind to PI3K and AKT, and limit their activation [24]. Pancreatic cancer is driven by KRAS and TP53 mutations. However, we knew little about the relationship between these two genes. Recently, Escobar-Hoyos et al. discovered that $\mathrm{p} 53-\mathrm{R} 175 \mathrm{H}$ increases the expression of $h n R N P K$, which is a splicing regulator, resulting in the production of isoforms of GTPase-activating proteins (GAPs). These GAP isoforms lost their function to contact and inactivate mutant KRAS, so KRAS downstream signaling pathways are turned on and contribute to tumor growth [25]. All these findings suggest that $\mathrm{p} 53-\mathrm{R} 175 \mathrm{H}$ gains the function of promoting tumor-cell growth in many kinds of cancer types and by different kinds of molecular mechanisms (Table 3). 
Table 3. Summary of p53-R175H gain-of-function of promoting cancer cell growth.

\begin{tabular}{|c|c|c|c|c|}
\hline Tumor Type & $\begin{array}{l}\text { Same Function } \\
\text { Mutations }\end{array}$ & $\begin{array}{c}\mathrm{R} 175 \mathrm{H} \\
\text { Interacting Protein }\end{array}$ & $\begin{array}{l}\text { Affected Downstream } \\
\text { Molecule or Pathway }\end{array}$ & Ref. \\
\hline Breast cancer & $\begin{array}{c}\mathrm{R} 248 \mathrm{Q}, \mathrm{R} 248 \mathrm{~W}, \mathrm{R} 249 \mathrm{~S}, \\
\mathrm{R} 273 \mathrm{H}\end{array}$ & ETS2 & $\begin{array}{c}\text { MLL1, MLL2, } \\
\text { MOZ/Global } \\
\text { chromatin remodeling }\end{array}$ & {$[21]$} \\
\hline Breast cancer & $\mathrm{R} 248 \mathrm{Q}, \mathrm{R} 273 \mathrm{H}, \mathrm{R} 280 \mathrm{~K}$ & NF-Y, YAP & $\begin{array}{c}\text { Cyclin } A, \text { cyclin } B, \\
\text { and CDK1 genes } \\
\text { hnRNPK/GAP17 }\end{array}$ & [22] \\
\hline Pancreatic cancer & - & - & $\begin{array}{l}\text { isoforms/KRAS } \\
\text { signaling pathway }\end{array}$ & [25] \\
\hline Bladder, bone, and ovarian cancer & V157F, 248Q & - & GEF-H1 & [19] \\
\hline Colorectal and pancreatic cancer & - & - & GRO1 & [20] \\
\hline Breast, colorectal, and lung cancer & $\mathrm{R} 273 \mathrm{H}$ & - & CDC7, Dbf4 & [23] \\
\hline Breast and prostate cancer & R280K & DAB2IP & PI3K/AKT1 & [24] \\
\hline
\end{tabular}

\subsection{Promoting Tumor Migration, Invasion, and Metastasis}

p53-R175H promotes tumor growth and increases its mobility. In 2000, Liu et al. first observed this phenomenon in heterozygous $\mathrm{p} 53^{\mathrm{R} 172 \mathrm{H}}$ mice (mouse $\mathrm{R} 172 \mathrm{H}$ refers to human $\mathrm{R} 175 \mathrm{H})$ [26]. They generate mice containing $\mathrm{p} 53^{\mathrm{R} 172 \mathrm{H} /+}$. Comparing to $\mathrm{p} 53^{-/+}$mice, $\mathrm{p} 53^{\mathrm{R} 172 \mathrm{H} /+}$ mice have a higher frequency to develop carcinomas and osteosarcoma, and these carcinomas and osteosarcoma also have a high frequency to metastasize. However, osteosarcoma developed in $\mathrm{p} 53^{-/+}$mice rarely metastasize. This result implied that $\mathrm{p} 53-$ $\mathrm{R} 175 \mathrm{H}$ gains function in promoting tumor metastasis [26]. Morton et al. also found that p53-R175H promoted tumor metastasis in the KRAS/TP53 mutation pancreatic ductal adenocarcinoma (PDAC) mouse model. p53-R172H mice have similar potential to develop PDAC comparing to p53-null mice. However, only tumor cells containing p53-R172H have the invasive ability [27]. Weissmueller et al. reported that mutant p53 binds to tumor suppressor p73 and prevents p73 binding to the NF-YA, NF-YB, and NF-YC complex. Therefore, the NF-Y complex can transactivate PDGFRb, which is an essential gene to pancreatic cancer cell invasion [28]. p73 shows a high structural resemblance to p53. TAp73, an isoform of $\mathrm{p} 73$, can serve as a tumor suppressor by inducing DNA repair, cell-cycle arrest, and apoptosis [29]. However, another p73 isoform, $\Delta \mathrm{Np} 73$, which lacks the Nterminus, has oncogenic functions by interacting with and inhibiting the function of TAp73 and p53 [30]. The stagnant of p53-targeted drug development might be caused by the ignorance of the importance of p73 in cancer eradication [31]. Mutant p53 can also exert its gain of function by inhibiting p73 [28]. Several promising drugs that can repurpose p73, such as ALA-protoporphyrin IX and verteporfin, are under development [31]. In addition, in breast MDA-MB-231 cells, TGF $\beta$ and oncogenic RAS promote the interaction between mutant p53 and SMAD2 by triggering the phosphorylation of the mutant p53 N-terminus through $\mathrm{CK} 1 \varepsilon / \delta$ kinases. Phosphorylated p53-R175H is able to bind to and inhibit tumor suppressor p63 with the help of SMAD2. p63 regulates many metastasisrelated genes. Therefore, $\mathrm{p} 53-\mathrm{R} 175 \mathrm{H}$ promotes metastasis by inhibiting the $\mathrm{p} 63$ pathway in breast cancer [32]. Additionally, p53-R175H promotes cancer-cell metastasis by activating EGFR/PIK3/AKT signaling pathway. Dong et al. observed that EGFR is activated after overexpressing p53-R175H in human endometrial-cancer cell line KLE, and is essential to its migration and invasion properties [33]. Muller et al. observed this phenomenon in breast cancer, and found that p53-R175H and p53-R273H enhance EGFR and integrin trafficking depending on the Rab-coupling protein (RCP), resulting in the activation of the EGFR and integrin pathway, and the promotion of cell migration and invasion [34]. Moreover, Zhang et al. discovered that RCP upregulated by mutant p53s is critical to the exosome-mediated Hsp90a secretion and causes a more invasive phenotype [35]. p53-R175H also affects the microRNA expression of cancer cells. p53-R175H, p53-R273H, and p53- C135Y directly bind to the promoter of $\mathrm{miR}-130 \mathrm{~b}$ and suppress its expression. miR-130b negatively regulates the epithelial-to-mesenchymal transition (EMT) promoting gene ZEB1. Therefore, p53-R175H 
exerts its prometastatic ability through the miR-130b-ZEB1 axis in endometrial-cancer cells [36]. p53-R175H also inhibits miR-142-3p, which leads to PDAC cell progression and metastasis. p53-R175H transcriptionally upregulates DNA methyltransferase 1 (Dnmt1), resulting in the hypermethylation of the CpG islands of miR-142-3p, which is associated with tumor progression and metastasis [37]. In breast cancer, p53-R175H, p53-R273H, or p53-R280K interacts with HIF-1 $\alpha$, and transcriptionally upregulates miR-30d, which causes the enhancement of vesicular trafficking and secretion, leading to the remodeling of the extracellular matrix and the establishment of a microenvironment suitable for tumor growth and metastasis [38]. These findings suggest that p53-R175H-regulated microRNAs play roles in tumor metastasis. In prostate cancer, both inactivated p53 and p53-R175H upregulate cell-cycle progression genes. However, p53-R175H additionally upregulates developmental genes, including EMT regulator gene TWIST1. p53-R175H increases the expression of TWIST1 by downregulating BMI-1, which maintains the level of epigenetic repression marker $\mathrm{H} 3 \mathrm{~K} 27 \mathrm{me} 3$, causing the epithelial-mesenchymal transition and invasion of prostate-cancer cells [39]. Yeudall et al. reported that, in several cancer types, p53$\mathrm{R} 175 \mathrm{H}, \mathrm{p} 53-\mathrm{R} 273 \mathrm{H}$, and p53-R281G contribute to cancer-cell migration by increasing the expression of several CXC-chemokines, including CXCL5, CXCL8, and CXCL12 [40]. In colorectal cancer, p53-R175H, p53-R248W, and p53-R273H can bind to SUMO-specific protease 1 (SENP1) and inhibit its de-SUMOylation function, causing the accumulation of SUMOylated Rac1, which is an activated form of RAC1 that promotes tumor growth and metastasis [41] (Table 4).

Table 4. Summary of p53-R175H gain-of-function of promoting tumor migration, invasion, and metastasis.

\begin{tabular}{|c|c|c|c|c|}
\hline Tumor Type & $\begin{array}{c}\text { Same Function } \\
\text { Mutations }\end{array}$ & $\begin{array}{c}\mathrm{R} 175 \mathrm{H} \\
\text { Interacting Protein }\end{array}$ & $\begin{array}{c}\text { Affected Downstream Molecule or } \\
\text { Pathway }\end{array}$ & Ref. \\
\hline Breast cancer & - & p63, Smad2 & p63 target genes & [32] \\
\hline Breast cancer & $\mathrm{R} 273 \mathrm{H}$ & - & RCP/EGFR and integrin/PI3K/AKT & [34] \\
\hline Breast cancer & $\mathrm{R} 273 \mathrm{H}$ & - & RCP/Hsp90a secretion & [35] \\
\hline Breast cancer & $\mathrm{R} 273 \mathrm{H}, \mathrm{R} 280 \mathrm{~K}$ & HIF- $1 \alpha$ & $\begin{array}{l}\text { miR-30d/accelerated vesicular } \\
\text { trafficking }\end{array}$ & [38] \\
\hline Colorectal cancer & R248W, R273H & SENP1 & Activation of Rac1 by SUMOylation & [41] \\
\hline Endometrial cancer & $\mathrm{R} 273 \mathrm{H}, \mathrm{C} 135 \mathrm{Y}$ & - & miR-130b/ZEB1/Snail/E-cad & [36] \\
\hline Pancreatic cancer & - & p73 & $\begin{array}{l}\text { NF-YA, NF-YB, and NF-YC } \\
\text { complex/PDGFRb }\end{array}$ & {$[28]$} \\
\hline Pancreatic cancer & - & - & Dnmt1/MiR-142-3p & [37] \\
\hline Prostate cancer & - & - & BMI-1/Twist1 & [39] \\
\hline $\begin{array}{l}\text { Breast, lung, and skin } \\
\text { cancer }\end{array}$ & R273H, D281G & - & CXCL5, CXCL8, and CXCL12 & [40] \\
\hline
\end{tabular}

\subsection{Promoting Tumor Initiation and Conferring Stemness}

Since TP53 mutations act as a driver in many cancer types [42], it is very likely that p53-R175H gains function in inducing tumorigenesis. Sarig et al. found that the reprogramming process of mouse embryonic fibroblasts (MEFs) expressing p53-R172H is enhanced comparing with p53 knockout MEFs. In addition, reprogrammed p53-R172H MEFs lost differentiation capacity and gained tumor initiation capacity [43]. Grespi et al. further found that p53 wild-type MEFs and p53-R172H MEFs have different expressions of microRNAs, which are associated with stemness, differentiation, and tumor suppression, implying that p53-R172H MEFs might gain tumor initiation capacity by regulating several microRNAs [44]. In the breast-cancer transgenic mouse model, p53-R175H/mWNT mice tend to develop multiple tumors, while most p53-/- / mWNT mice develop one tumor. p53R175H expands mammary epithelial stem cells (MESCs) through the inactivation of ATM and causes tumorigenesis [45]. Expressing p53-R175H in human astrocytes also enhances its neurosphere-forming ability and increases cancer-stem-cell-like marker expression. On the basis of previous studies, p53-R175H can activate the EGFR integrin/PI3K/AKT pathway and promote tumor proliferation and metastasis [24,32,33]. In human astrocytes 
overexpressing $\mathrm{p} 53-\mathrm{R} 175 \mathrm{H}, \mathrm{AKT} 2$ that is activated by $\mathrm{p} 53-\mathrm{R} 175 \mathrm{H}$ phosphorylates the WASP interacting protein (WIP), and the phosphorylated WIP stabilizes the YAP/TAZ complex, causing the transcriptional activation of genes that promotes cancer-stem-cell survival, including CYR61, CTGF, BIRC5 (also known as SURVIVIN), and CAV2 [46]. p53-R175H, p53-R248W, and p53-R273H increase the expression of colorectal cancer stem-cell markers CD44, LGR5, and ALDH in several colon cancer cell lines, and promote their tumor initiation capacity. Colon-cancer cells with high ALDH1 expression are also more resistant to cisplatin [47]. p53-R175H confers sphere-formation capacity on pancreatic-cancer cell line HPNE with KRAS-G12D mutation. In HPNE cells, p53-R175H induces the expression of HSP70, which binds to p53-R175H and maintains its stability [48]. Several p53 hotspot mutations promote hematopoietic stem- and progenitor cell (HSPC) expansion, and resistance to irradiation. p53-R175H, p53-R248W, and p53-R273H can directly bind to EZH2 and recruit EZH2 to chromatin, resulting in a global increase in H3K27me3 level and driving leukemia development [49]. p53-R175H, p53-R248W, and p53-R273H also upregulate EZH2 by repressing miR-26a in endometrial carcinoma [50]. However, p53-R175H acts as a tumor suppressor in certain conditions. Kadosh et al. discovered that, in the proximal gut, p53-R175H and p53-R273H inhibited the WNT signaling pathway by preventing the binding of transcription factor TCF4 to $\beta$-catenin. Interestingly, in the distal gut, gallic acid secreted by gut microbes abolished the effect of mutant p53s, thus turning on the WNT pathway and driving tumor initiation [51]. During tumor metastasis, cancer stem cells play an important role because they have self-renewal and tumor-initiation abilities. Increasing evidence shows that the EMT program is associated with the stemness program in cancer cells [52]. For example, in endometrial cancer, p53-R175H reduces miR-130b expression by directly binding to its promoter, thus inhibiting the expression of miR-130b target gene $Z E B 1$, which functions as a transcriptional factor that is critical to cell EMT and stemness. ZEB1 can promote EMT by upregulating SNAI1, which can suppress the expression of epithelial marker E-cadherin. ZEB1 also promotes stemness by upregulating BMI-1, which is a chromatin remodeler that can reduce the expression of stemness-related transcription factors NANOG and KLF4 [36]. Moreover, ZEB1 upregulates chemoresistance-related genes MDR1 and MRP1 [36], in agreement with the concept that cancer stem cells are more resistant to chemotherapy [53] (Table 5).

Table 5. Summary of p53-R175H gain-of-function promoting tumor initiation and conferring stemness.

\begin{tabular}{|c|c|c|c|c|}
\hline Tumor Type & $\begin{array}{l}\text { Same Function } \\
\text { Mutations }\end{array}$ & $\begin{array}{c}\mathrm{R} 175 \mathrm{H} \\
\text { Interacting Protein }\end{array}$ & $\begin{array}{c}\text { Affected Downstream Molecule or } \\
\text { Pathway }\end{array}$ & Ref. \\
\hline Colorectal cancer & R248W, R273H & - & $\begin{array}{l}\text { Stem cell markers CD44, LGR5, and } \\
\text { ALDH1 }\end{array}$ & [47] \\
\hline Colorectal cancer & $\mathrm{R} 273 \mathrm{H}$ & TCF4 & $\beta$-catenin/WNT signaling pathway & [51] \\
\hline Leukemia & $\mathrm{R} 248 \mathrm{~W}, \mathrm{R} 273 \mathrm{H}$ & $\mathrm{EZH} 2$ & Global increase of H3K27me3 & [49] \\
\hline Brain and breast cancer & $\mathrm{R} 273 \mathrm{H}$ & - & $\begin{array}{c}\text { RCP/EGFR and } \\
\text { integrin/PI3K/AKT/WIP/YAP, TAZ }\end{array}$ & {$[46]$} \\
\hline
\end{tabular}

\subsection{Promoting Tumor Drug Resistance, Inflammation, Angiogenesis, and Metabolic Reprogramming}

Cancer stem cells are both responsible for tumor initiation, metastasis, and drug resistance [54], and associated with angiogenesis property [55] and metabolic reprogramming [56]. Several studies reported that many chemotherapy treatments have progressively become ineffective for patients with TP53 mutation [57]. The inflammatory microenvironment can also confer cancer cells stemness and EMT [58]. It is very likely that mutant p53s are involved in these biological processes. Scian et al. overexpressed p53-R175H, p53-R273H, and p53-D281G in p53-null human lung-carcinoma cells H1299 and found that they are more resistant to common chemotherapy drug etoposide. These mutant p53s can bind to the promoter of the $N F-\kappa B 2$ gene and increase its expression. NF- $\kappa B$ is involved in the antiapoptotic activity of cancer cells. Targeting the NF- $\kappa B 2$ gene by 
siRNA in H1299 expressing mutant p53 can restore its sensitivity towards etoposide [59]. Donzelli et al. also found that. in lung-carcinoma cell lines H1299 and A549, p53-R175H enhanced the expression of miR128-2 through binding to the promoter of its host gene ARPP21. miR128-2 inhibited E2F5 expression and thus decreased the expression of E2F5 target gene $p 21$. In cells overexpressing p53-R175H, p21 localized to the cytoplasmic compartment and exerted antiapoptotic function through preventing cleavage of procaspase- 3 under a DNA damage condition. Therefore, p53-R175H confers lung-carcinoma cell resistance towards chemotherapy drugs doxorubicin, cisplatin, and 5-fluorouracil through the miR128-2/E2F5/p21 axis [60]. p53-R175H also exerts drug-resistance function through the proteasome degradation pathway. Wild-type p53 binds to the promoter of proteasome activator gene $R E G \gamma$ and recruits corepressor SMAD3 to repress its expression. p53-R175H also binds to the promoter of REG $\gamma$ but prevents SMAD3 binding, thus upregulating $R E G \gamma$ expression and causing the degradation of several tumor suppressors including p53, p21, and p16, leading to cell proliferation and drug resistance [61]. SLC25A1 is another gene transcriptionally activated by mutant p53s. Upregulation of SLC25A1 in the lung- or breast-cancer cells can cause resistance to platinum-based chemotherapy drugs [62]. In colon-cancer cells with DNA damage triggered by chemotherapy drugs, p53-R175H, p53-R248W, and p53-R273H upregulate ephrin-B2 coding gene EFNB2 by binding to its promoter companies by NF-Y and p300. Upregulated ephrin-B2 promotes resistance to 5-FU by increasing resistance-associated gene $A B C G$ expression through SRC/FAK/MEKK/MEK/JNK/c-JUN phosphorylation cascade. Ephrin-B2 induced by mutant p53 also promotes EMT, tumorigenesis, and proliferation through different SRC downstream phosphorylation cascades, emphasizing the important role of mutant p53 in tumor development [63].

p53-R175H also promotes angiogenesis. In breast cancer, p53-R175H and E2F1 bind to the promoter of ID4 and enhance its expression. ID4 further binds to and stabilizes the mRNAs of IL8 and GRO- $\alpha$, which are proangiogenic factors [64]. In 2005, it was reported that mutant p53s could upregulate the NF- $\kappa B 2$ gene [59]. Transcription factor NF- $\kappa B$ plays a critical role in inflammatory responses and cancer development [65]. Weisz et al. reported that in the lung- and breast-cancer cell lines, p53-R175H can augment the induction of NF$\mathrm{\kappa B}$ expression in response to $\mathrm{TNF} \alpha$, which is a cytokine presented in a chronic inflammation environment, thereby promoting cancer progression. Cooks et al. further discovered that p53-R175H prolongs the activation period of NF- $\mathrm{B}$ triggered by $\mathrm{TNF} \alpha$. Therefore, mice expressing p53-R175H are prone to develop inflammation-associated colon cancer [66]. p53-R175H can also promote the generation of inflammatory tumor microenvironment by regulating the secreted interleukin-1 receptor antagonist (sIL-1Ra). Mutant p53 but not wild-type p53 binds to the promoter of sIL-1Ra with corepressor MAFF and suppresses sIL-1Ra expression. Therefore, proinflammation cytokine IL-1 beta is not antagonized by sIL-1Ra [67]. Mutant p53 can also alter the metabolism of cancer cells. p53-R175H, p53-R248Q, and p53-R273H can induce the translocation of GLUT1 to the cell membrane through increasing the expression of small GTPases RhoA and ROCK, resulting in the stimulation of the Warburg effect, which means that cancer cells generate energy by using aerobic glycolysis instead of oxidative phosphorylation [68]. In head and neck cancer, under glucose deprivation conditions, p53-P151S, p53-R175H, p53-G245C, and p53-R282W localize to the cytoplasm and inhibit the phosphorylation and activation of AMPK, which is an energy sensor and can repress aerobic glycolysis. Therefore, mutant p53s induce the Warburg effect to promote tumor growth by inhibiting AMPK phosphorylation [69] (Table 6). 
Table 6. Summary of p53-R175H gain-of-function of promoting tumor drug-resistance, inflammation, angiogenesis, and metabolic reprogramming.

\begin{tabular}{|c|c|c|c|c|c|}
\hline Gain-of-Function & Tumor Type & $\begin{array}{c}\text { Same Function } \\
\text { Mutations }\end{array}$ & $\begin{array}{c}\mathrm{R} 175 \mathrm{H} \\
\text { Interacting Protein }\end{array}$ & $\begin{array}{c}\text { Affected Downstream Molecule } \\
\text { or Pathway }\end{array}$ & Ref. \\
\hline \multirow{5}{*}{ Chemoresistance } & Colorectal cancer & R273H, R248W & NF-Y, p300 & $\begin{array}{c}\text { Ephrin-B2/SRC/FAK/ } \\
\text { MEKK/MEK/JNK/c- } \\
\text { JUN/ABCG }\end{array}$ & [63] \\
\hline & Lung cancer & R273H, D281G & - & NF- $k B 2$ & [59] \\
\hline & Lung cancer & - & - & $\begin{array}{l}\text { miR128-2/E2F5/p21/pro- } \\
\text { caspase-3 }\end{array}$ & {$[60]$} \\
\hline & \multirow{2}{*}{$\begin{array}{c}\text { Breast, colorectal, } \\
\text { head and neck, and } \\
\text { lung cancer } \\
\text { Breast and lung } \\
\text { cancer }\end{array}$} & $\begin{array}{l}\text { R248W, R273H, } \\
\text { R280K, R282W }\end{array}$ & SMDA3 & $\begin{array}{l}\text { REG } \gamma / \text { proteasome } \\
\text { activation/p53, p21, } \\
\text { and p16 degradation }\end{array}$ & [61] \\
\hline & & $\begin{array}{l}\text { G245A, D281G, } \\
\text { R273H, R280K }\end{array}$ & - & SLC25A1 & [62] \\
\hline Angiogenesis & Breast cancer & R273H, R280K & E2F1 & ID4/IL8, GRO- $\alpha$ & [64] \\
\hline \multirow{2}{*}{$\begin{array}{l}\text { Inflammatory } \\
\text { response }\end{array}$} & Colorectal cancer & $\mathrm{R} 273 \mathrm{H}$ & - & $\begin{array}{l}N F-\kappa B \text { expression in } \\
\text { response to TNF } \alpha\end{array}$ & [66] \\
\hline & $\begin{array}{l}\text { Breast, colorectal, } \\
\text { and liver cancer }\end{array}$ & R273H, R280K & MAFF & sIL-1Ra/IL-1 $\beta$ & [67] \\
\hline \multirow{2}{*}{$\begin{array}{l}\text { Metabolic } \\
\text { reprogramming }\end{array}$} & $\begin{array}{l}\text { Breast and lung } \\
\text { cancer }\end{array}$ & R248Q, R273H & - & $\begin{array}{c}\text { RhoA, ROCK/GLUT1 } \\
\text { translocation/Warburg effect }\end{array}$ & [68] \\
\hline & $\begin{array}{l}\text { Head and neck } \\
\text { cancer }\end{array}$ & $\begin{array}{l}\text { P151S, G245C, } \\
\text { R282W }\end{array}$ & AMPK & $\begin{array}{c}\text { AMPK inactivation/Warburg } \\
\text { effect }\end{array}$ & [69] \\
\hline
\end{tabular}

\section{Targeting p53-R175H for Cancer Therapy}

Because p53 is a very common mutated gene across many cancer types, scientists have attempted to develop drugs or strategies to target mutant p53 for a long time. There are three kinds of strategies which are reactivating the wild-type p53 function by promoting proper folding and stabilization of p53 mutants, promoting mutant p53 degradation, and immunotherapies based on mutant p53 neoantigen recognition. In this chapter, we summarize the current status of p53-R175H-targeted drugs development (Table 7).

Table 7. Summary of drugs and strategies targeting p53-R175H for cancer therapy.

\begin{tabular}{|c|c|c|c|c|c|c|c|}
\hline Concept & Strategy & Drug & $\begin{array}{c}\text { Other Targeted } p 53 \\
\text { Mutants }\end{array}$ & Clinical Trial & Phase & Status & Ref. \\
\hline \multirow{18}{*}{$\begin{array}{l}\text { Reactivating } \\
\text { wild-type p53 } \\
\text { function }\end{array}$} & \multirow{16}{*}{$\begin{array}{l}\text { targeting the cysteine } \\
\text { residues of p53 }\end{array}$} & PRIMA-1 & $\mathrm{R} 273 \mathrm{H}$ & - & - & - & [70] \\
\hline & & \multirow{7}{*}{ APR-246 } & \multirow{7}{*}{$\mathrm{R} 273 \mathrm{H}$} & NCT03931291 & 2 & $\begin{array}{l}\text { Active, not } \\
\text { recruiting }\end{array}$ & \multirow{7}{*}{ [71] } \\
\hline & & & & NCT04214860 & 1 & Recruiting & \\
\hline & & & & NCT04383938 & 1,2 & Recruiting & \\
\hline & & & & NCT03745716 & 3 & $\begin{array}{c}\text { Active, } \\
\text { not recruiting }\end{array}$ & \\
\hline & & & & NCT04419389 & 1,2 & Recruiting & \\
\hline & & & & NCT03588078 & 1,2 & $\begin{array}{c}\text { Active, } \\
\text { not recruiting }\end{array}$ & \\
\hline & & & & NCT03072043 & 1,2 & $\begin{array}{l}\text { Active, } \\
\text { not recruiting }\end{array}$ & \\
\hline & & MIRA-1 & $\mathrm{R} 273 \mathrm{H}$ & - & - & - & [72] \\
\hline & & STIMA-1 & $\mathrm{R} 273 \mathrm{H}$ & - & - & - & [73] \\
\hline & & Stictic acid & - & - & - & - & [74] \\
\hline & & \multirow[t]{2}{*}{ KSS-9 } & - & - & - & - & \multirow[t]{2}{*}{ [75] } \\
\hline & & & \multirow[t]{4}{*}{ Structural p53 mutants } & NCT04695223 & 2 & Recruiting & \\
\hline & & Arsenic & & NCT03855371 & 1 & Recruiting & \multirow{3}{*}[76]{} \\
\hline & & trioxide & & NCT03377725 & 3 & unknown & \\
\hline & & & & NCT04869475 & 2 & Recruiting & \\
\hline & Other & ZMC1 & - & - & - & - & [77] \\
\hline & strategies & ReACp53 & R248Q & - & - & - & [78] \\
\hline
\end{tabular}


Table 7. Cont.

\begin{tabular}{|c|c|c|c|c|c|c|c|}
\hline Concept & Strategy & Drug & $\begin{array}{c}\text { Other Targeted p53 } \\
\text { Mutants }\end{array}$ & Clinical Trial & Phase & Status & Ref. \\
\hline \multirow{4}{*}{$\begin{array}{l}\text { Promoting } \\
\text { mutant } p 53 \\
\text { degradation }\end{array}$} & \multirow[t]{2}{*}{$\begin{array}{l}\text { Targeting the } \\
\text { mevalonate pathway }\end{array}$} & Atorvastatin & \multirow[t]{2}{*}{$\begin{array}{l}\text { Structural } \\
\text { p53 mutants }\end{array}$} & $\begin{array}{l}\text { NCT03560882 } \\
\text { NCT04767984 }\end{array}$ & $\begin{array}{l}1 \\
2\end{array}$ & $\begin{array}{l}\text { Recruiting } \\
\text { Not yet } \\
\text { recruiting }\end{array}$ & {$[79,80]$} \\
\hline & & & & NCT03358017 & 2 & Recruiting & \\
\hline & \multirow{2}{*}{$\begin{array}{l}\text { HDAC } \\
\text { inhibitor } \\
\text { Hsp90 } \\
\text { inhibitor }\end{array}$} & SAHA & Broad effect & NCT02042989 & 1 & $\begin{array}{c}\text { Active, } \\
\text { not recruiting }\end{array}$ & [81] \\
\hline & & Ganetespib & Broad effect & - & - & - & [82] \\
\hline $\begin{array}{l}\text { Immuno- } \\
\text { therapy }\end{array}$ & $\begin{array}{l}\text { Bispecific } \\
\text { antibody }\end{array}$ & $\mathrm{H} 2-\mathrm{scDb}$ & - & - & - & - & [83] \\
\hline
\end{tabular}

\subsection{Reactivating Wild-Type p53 Function}

Many p53 mutations are missense mutations, generating proteins that only have one different amino acid from the wild-type p53 protein. Therefore, reactivating mutant p53 might be a strategy for cancer therapy. Scientists found that many p53 missense mutations can increase the free energy of the protein and decrease structural stability [84]. In the past two decades, many research groups put much effort into finding small molecules that can bind to and stabilize the p53 mutants, thereby reactivating their normal function. By different kinds of screening strategies such as protein screening, cellular screening, or molecular modeling, several small molecules have been identified that can restore the wild-type p53 function. Among them, there is a large group of molecules targeting the cysteine residues in $\mathrm{p} 53$ protein. These cysteine-binding compounds are soft electrophiles and can conjugate to the thiol group of the cysteine, which is a nucleophile, in mutant p53 proteins. This kind of chemical reaction is called the Michael addition, and these cysteine-binding compounds are referred to as Michael acceptors. PRIMA-1, which is a quinuclidinone, was identified by cellular screening on the basis of cancer-cell lines carrying tetracycline-regulated mutant p53. PRIMA- 1 can suppress the growth of several types of tumor cells carrying p53- $\mathrm{R} 175 \mathrm{H}$ and $\mathrm{p} 53-\mathrm{R} 273 \mathrm{H}$, but cannot inhibit the growth of tumor cells carrying wild-type p53 [70]. APR-246, a methylated form of PRIMA-1, is more active than PRIMA-1 and has a synergistic effect with cisplatin to inhibit the tumor xenograft growth in SCID mice [71]. Lambert et al. further discovered that both PRIMA-1 and APR-246 are converted into methylene quinuclidinone (MQ), which is a Michael acceptor that can conjugate to thiol groups in mutant $p 53$ proteins, while $\mathrm{N}$-acetylcysteine (NAC) completely blocked its function. MIRA-1 [72] and STIMA-1 [73], which are p53$\mathrm{R} 175 \mathrm{H}$ and p53-R273H reactivators, also have reactive groups similar to PRIMA-1 and APR-246 that can act as Michael acceptors [85]. Wassman et al. further used in silico docking to find that PRIMA-1, APR-246, MIRA-1, and STIMA-1 all bind to the L1/S3 pocket of p53-R175H, which contains Cys124, Cys135, and Cys141 residues. The mutation of Cys124 can abolish the p53 reactivating effect of these compounds. They also identified stictic acid as a p53 reactivator by ensemble-based virtual screening against the L1/S3 pocket of the mutant $\mathrm{p} 53$. Treating cancer cell lines containing $\mathrm{p} 53-\mathrm{R} 175 \mathrm{H}$ with stictic acid can increase the expression of the wild-type p53 target gene $p 21$ [74]. Peng et al. found that PRIMA- 1 and APR-246 reactivate the mutant $p 53$ and inhibit thioredoxin reductase 1 (TrxR1), likely by Michael addition to the selenocysteine residue (U498), and convert its function into an NADPH oxidase, thereby increasing oxidative stress [86]. Tumor cells expressing mutant $p 53$ are more sensitive to reactive oxygen species (ROS) because of their aberrant metabolic pathways. For example, mutant p53 can downregulate AMPK, thereby reducing the activity of its downstream molecules PGC- $1 \alpha$ and UCP2, which are involved in ROS scavenging [69]. Disrupting the REDOX balance might be a strategy to treat tumors containing mutant p53 [87]. APR-246, which can both reactivate mutant p53 proteins and increase the level of intracellular ROS, is a promising drug for p53-mutant tumors. Several ongoing clinical trials are testing the safety and efficacy of APR-246 for different 
cancer types (NCT03931291, NCT04214860, NCT04383938, NCT03745716, NCT04419389, NCT03588078, and NCT03072043 at ClinicalTrials.gov (accessed on 1 July 2021)). The latest result of the phase 2 trial (NCT03072043) showed combination treatment with eprenetapopt (APR-246) and azacitidine is well tolerated yielding high rates of clinical response and molecular remissions in patients with TP53-mutant myelodysplastic syndromes [88,89]. KSS-9 is a piperlongumine derivative with the insertion of combretastatin A4 at the C-7 position. It retained the ROS elevation function of piperlongumine and the microtubule disruption function of combretastatin A4. Surprisingly, KSS-9 also showed capacity to reactivate p53-R175H by performing Michael addition to its cysteine residues [75]. Recently, it has been reported that the cysteine residues of p53 mutants are reactive to arsenic. Chen et al. found that most structural p53 mutants can be stabilized by arsenic trioxide (ATO), and some of them are transcriptionally rescued, while DNA contact p53 mutants cannot be rescued by ATO. Crystal structures of p53 mutants incubated with AsI3 revealed that the arsenic atom is coordinated by Cys124, Cys135, and Cys141. This is an inspiring discovery because ATO was used to treat acute promyelocytic leukemia, and the result of in vitro and in vivo experiments showed that ATO suppressed tumor progression by reactivating many kinds of structural p53 mutants [76]. Several ongoing clinical trials are testing the safety and the efficacy of arsenic trioxide for acute myeloid leukemia, myelodysplastic syndromes, and refractory tumor with TP53 mutation (NCT03931291, NCT04214860, NCT04383938, NCT03745716, NCT04419389, NCT03588078, and NCT03072043 at ClinicalTrials.gov (accessed on 1 July 2021)).

In addition to targeting cysteine residues of p53 mutants, there are other strategies to reactivate p53 mutants. ZMC1, which is a kind of thiosemicarbazone, was identified by screening NCI database substances that inhibit the growth of cancer cell lines expressing p53 hotspot mutations compared to that expressing wild-type p53. ZMC1 as a $\mathrm{Zn}^{2+}$ chelator can buffer the intracellular $\mathrm{Zn}^{2+}$ concentration, thereby improving the binding of $\mathrm{Zn}^{2+}$ specifically to p53-R175H [77]. It was known that the binding of $\mathrm{Zn}^{2+}$ is very important to the stability of wild-type p53 [8]. R175 residue lies closely to the $\mathrm{Zn}^{2+}$ binding site and the $\mathrm{R} 175 \mathrm{H}$ mutation distorts the local structure, thereby affecting the $\mathrm{Zn}^{2+}$ binding ability [90]. ZMC1 reactivates p53-R175H and induces oxidative stress, likely by the ability of thiosemicarbazones to create hydroxyl radicals through the Fenton reaction [77]. Another thiosemicarbazone, COTI-2, can also reactivate p53 mutants and inhibit the PI3K-AKT pathway [91]. Some types of p53 mutants can form aggregates. Soragni et al. designed a peptide called ReACp53 that inhibits p53-R175H or p53-R248Q aggregate formation by targeting p53 segments 252-LTIITLE-258, which are essential for p53 aggregation. The inhibition of aggregation by ReACp 53 reactivates p 53 mutants and induces cell death and cell-cycle arrest in high-grade serous ovarian carcinomas [78]. The stability of p53 can be regulated by several heat-shock proteins or chaperones [92]. Hiraki et al. identified a small molecule called chetomin that can bind to Hsp40 and enhance the binding capacity of Hsp40 to p53- $\mathrm{R} 175 \mathrm{H}$, resulting in the conformational change of p53- $\mathrm{R} 175 \mathrm{H}$ into a wildtype-like structure [93].

\subsection{Promoting Mutant $p 53$ Degradation}

Promoting mutant $p 53$ degradation is another strategy to treat TP53-mutated cancers. The intracellular level of mutant p53 is mediated by DNAJA1, a member of the Hsp40 family. Statins were identified by cell-based screening as a compound that can degrade p53-R175H. Statins inhibit the mevalonate pathway. Mevalonate-5-phosphate (MVP), a metabolic intermediate in the mevalonate pathway, is reduced, thereby inhibiting the binding between p53-R175H and DNAJA1. p53-R175H, without the protection of DNAJA1, is led to proteasomal degradation by Hsc70-interacting protein (CHIP) mediated ubiquitination [79]. Mutant p53 can be stabilized by HDAC6-mediated Hsp90 deacetylation [81]. HDAC6/Hsp90-dependent mutant p53 accumulation is dependent on RhoA geranylgeranylation, which is downstream of the mevalonate pathway and can be inhibited by statins [80]. Since statins are commonly used lipid-lowering agents, they are promising 
drugs that target the mutant p53. Currently, several ongoing clinical trials are testing the efficacy of atorvastatin on triple-negative breast cancer, acute myeloid leukemia, and colorectal carcinoma (NCT03358017, NCT03560882, and NCT04767984 at ClinicalTrials.gov (accessed on 1 July 2021)). Targeting HDAC6 and Hsp90 is another way to induce the degradation of p53 mutants. Li et al. reported that the FDA-approved HDAC inhibitor suberoylanilide hydroxamic acid (SAHA) downregulated mutant p53 but not wild-type p53 in protein level, and showed cytotoxicity to breast-cancer cell lines expressing p53 mutants [81]. Furthermore, the treatment that combines SAHA with Hsp90 inhibitor 17DMAG inhibited T-cell lymphomagenesis in p53 $3^{\mathrm{R} 172 \mathrm{H} / \mathrm{R} 172 \mathrm{H}}$ mice, and so did the Hsp90 inhibitor ganetespib alone treatment [82].

\subsection{Immunotherapy Based on Mutant p53 Neoantigen Recognition}

Since TP53 missense mutations encode mutant p53 proteins that have one amino acid different from wild-type p53, scientists have long considered whether these proteins can be presented by tumor cells or antigen-presenting cells, and can be a target for immunotherapy. In 2018, Hwang et al. successfully generated monoclonal antibodies against p53-R175H, p53-R248Q, and p53-R273H with high specificity by designing immunogens that are TrxA proteins fused with three copies of the mutant p53 sequence. These antibodies can be used in the clinic to detect the p53 status rapidly [94]. Lo et al. reported that some tumorinfiltrating lymphocytes (TILs) isolated from a patient with metastatic colorectal cancer were able to recognize p53-R175H restricted to HLA-A*0201. HLA-A*0201 is the most common allele in HLA-A2 subtypes, especially among general Caucasian populations [95]. Three T-cell receptors (TCRs) were identified that can recognize cell lines expressing both p53-R175H and HLA-A*0201 [96]. To understand whether the recognition of $p 53$ mutants by the TILs is a common phenomenon across different cancer types, TILs from 28 patients with several types of cancers were screened by autologous antigen-presenting cells that present corresponding p53 mutant peptides by electroporated with tandem minigenes or pulsed with peptides. TILs from $39 \%$ of patients were able to recognize mutant p53 peptides restricted to HLA class I or class II and be activated. This study suggested that p53 mutants could be a target for cancer immunotherapy [97]. Furthermore, peripheral blood lymphocytes (PBLs) from patients whose TILs were reactive to mutated p53 could also respond to antigen-presenting cells presenting p53 mutant peptides. PBLs can be obtained by non-invasive methods, making them a more accessible source of $\mathrm{T}$ cells for adoptive cell therapy [98]. Wu et al. deeply examined the structure of the TCR-p53R175HHLA-A2 complex to understand how p53R175H-reactive TCRs distinguish p53-R175H from the wild-type and found that TCRs were shifted towards the C-terminus of the p53$\mathrm{R} 175 \mathrm{H}$ peptide. This knowledge could contribute to the future design of TCRs against p53 mutants [99]. Recently, Hsiue et al. made a big step in the development of mutant p53 targeting immunotherapy by constructing bispecific antibody $\mathrm{H} 2-\mathrm{scDb}$ that could bind to the p53-R175H peptide-HLA-A*0201 complex with one arm and the TCR-CD3 with the other arm. Although the density of the p53-R175H peptide-HLA-A*0201 complex in the surface of tumor cells is very low, bispecific antibody $\mathrm{H} 2-\mathrm{scDb}$ activated $\mathrm{T}$ cells to kill tumor cells in vitro and in mice [83]. Mutant p53 peptide neoantigens are a promising target for cancer immunotherapy because of the high occurrence of TP53 missense mutation across cancer types.

\section{Conclusions}

By summarizing the p53-R175H gain-of-functions reported by different groups, $\mathrm{p} 53-$ $\mathrm{R} 175 \mathrm{H}$ and other p53 hotspot mutations were found to contribute to tumor development by promoting cancer cell proliferation, migration, invasion, initiation, metabolic reprogramming, angiogenesis, and conferring drug resistance to cancer cells (Table 2). The effect of mutant p53 in cancer cells is so broad and huge, giving it the title of "the guardian of the cancer cell" [100]. Furthermore, p53-R175H often executes its function by directly binding to promoters of genes and transcriptionally up- or down-regulating their expressions by 
recruiting cofactors or corepressors, respectively. p53-R175H interacts with other transcription factors such as p63, p53, ETS2, and NF-Y to interfere in the expression of their target genes. Different kinds of p53 mutants have unique functions. However, R273H, R248W, and R248Q have similar functions with those of R175H. The function of p53-R175H is highly dependent on the cellular context. p53-R175H influences different kinds of pathways in different kinds of cancer types. Currently, the p53-R175H gain-of-function study is intensive on several cancer types, including breast, lung, colorectal, and pancreatic cancers. However, TP53 is also highly mutated in other cancer types such as osteosarcoma, and ovarian, head and neck, esophageal, and brain cancers. More p53 gain-of-function studies are needed in these types of cancers in order to find the vulnerabilities of these cancer cells. Regarding treatment targeting p53- $\mathrm{R} 175 \mathrm{H}$, many small molecules were identified by screening that could reactivate p53 tumor-suppressor activities. Several small molecules were also found to promote the degradation of p53-R175H mutants by targeting heat-shock proteins that bind and stabilize p53-R175H. Recently, it was discovered that p53-R175H peptides-HLA complexes are presented on the cell surface of cancer cells, and T cells can distinguish them from the wild-type p53 peptide, making it become a promising target for cancer immunotherapies.

Author Contributions: Conceptualization, D.-F.L. and Y.-L.Y.; software, Y.-C.C., Y.-H.L. and H.H.W. writing - original draft preparation, Y.-T.C.; writing —review and editing, D.-F.L. and Y.-L.Y.; supervision, D.-F.L. and Y.-L.Y.; project administration, D.-F.L. and Y.-L.Y.; funding acquisition, D.-F.L. and Y.-L.Y. All authors have read and agreed to the published version of the manuscript.

Funding: This study was supported by grants from the Ministry of Science and Technology, Taiwan (MOST 109-2320-B-039-013-MY3); the China Medical University, Taiwan (CMU108-MF-01; CMU109-MF-03); the China Medical University Hospital, Taiwan (DMR-108-BC-4; DMR-108-BC-10; DMR-109-133; and DMR-110-046); and the Drug Development Center, China Medical University, from the Featured Areas Research Center Program within the framework of the Higher Education Sprout Project by the Ministry of Education (MOE) in Taiwan. D.-F.L. was supported by CPRIT RR160019, NIH/NCI R01CA246130, Rolanette and Berdon Lawrence bone disease program of Texas, and Pablove Foundation childhood cancer research grant (690785). D.-F.L. is a CPRIT Scholar in Cancer Research.

Data Availability Statement: Publicly available datasets were analyzed in this study. This data can be found here: [The TCGA database: (https:/ / www.cancer.gov/tcga) (accessed on 1 July 2021). The IARC TP53 database: (https://p53.iarc.fr/) (accessed on 1 July 2021)].

Acknowledgments: The results shown here are in whole or part based upon data generated by the TCGA Research Network: https:/ /www.cancer.gov/tcga (accessed on 1 July 2021).

Conflicts of Interest: The authors declare no conflict of interest.

\section{References}

1. Hanahan, D.; Weinberg, R.A. Hallmarks of cancer: The next generation. Cell 2011, 144, 646-674. [CrossRef]

2. Lane, D.P. Cancer. p53, guardian of the genome. Nature 1992, 358, 15-16. [CrossRef]

3. Guimaraes, D.P.; Hainaut, P. TP53: A key gene in human cancer. Biochimie 2002, 84, 83-93. [CrossRef]

4. Bouaoun, L.; Sonkin, D.; Ardin, M.; Hollstein, M.; Byrnes, G.; Zavadil, J.; Olivier, M. TP53 Variations in Human Cancers: New Lessons from the IARC TP53 Database and Genomics Data (R20). Hum. Mutat. 2016, 37, 865-876. [CrossRef] [PubMed]

5. Zhou, R.; Xu, A.; Gingold, J.; Strong, L.C.; Zhao, R.; Lee, D.F. Li-Fraumeni Syndrome Disease Model: A Platform to Develop Precision Cancer Therapy Targeting Oncogenic p53. Trends Pharmacol. Sci. 2017, 38, 908-927. [CrossRef]

6. Figueiredo, B.C.; Sandrini, R.; Zambetti, G.P.; Pereira, R.M.; Cheng, C.; Liu, W.; Lacerda, L.; Pianovski, M.A.; Michalkiewicz, E.; Jenkins, J.; et al. Penetrance of adrenocortical tumours associated with the germline TP53 R337H mutation. J. Med. Genet. 2006, 43, 91-96. [CrossRef] [PubMed]

7. Saha, T.; Kar, R.K.; Sa, G. Structural and sequential context of p53: A review of experimental and theoretical evidence. Prog. Biophys. Mol. Biol. 2015, 117, 250-263. [CrossRef] [PubMed]

8. Cho, Y.; Gorina, S.; Jeffrey, P.D.; Pavletich, N.P. Crystal structure of a p53 tumor suppressor-DNA complex: Understanding tumorigenic mutations. Science 1994, 265, 346-355. [CrossRef]

9. Baugh, E.H.; Ke, H.; Levine, A.J.; Bonneau, R.A.; Chan, C.S. Why are there hotspot mutations in the TP53 gene in human cancers? Cell Death Differ. 2018, 25, 154-160. [CrossRef] 
10. Quante, T.; Otto, B.; Brazdova, M.; Kejnovska, I.; Deppert, W.; Tolstonog, G.V. Mutant p53 is a transcriptional co-factor that binds to G-rich regulatory regions of active genes and generates transcriptional plasticity. Cell Cycle 2012, 11, 3290-3303. [CrossRef]

11. Stein, Y.; Rotter, V.; Aloni-Grinstein, R. Gain-of-Function Mutant p53: All the Roads Lead to Tumorigenesis. Int. J. Mol. Sci. 2019, 20, 6197. [CrossRef]

12. Li, L.; Li, X.; Tang, Y.; Lao, Z.; Lei, J.; Wei, G. Common cancer mutations R175H and R273H drive the p53 DNA-binding domain towards aggregation-prone conformations. Phys. Chem. Chem. Phys. 2020, 22, 9225-9232. [CrossRef]

13. Xu, J.; Reumers, J.; Couceiro, J.R.; De Smet, F.; Gallardo, R.; Rudyak, S.; Cornelis, A.; Rozenski, J.; Zwolinska, A.; Marine, J.C.; et al. Gain of function of mutant p53 by coaggregation with multiple tumor suppressors. Nat. Chem. Biol. 2011, 7, 285-295. [CrossRef]

14. Dittmer, D.; Pati, S.; Zambetti, G.; Chu, S.; Teresky, A.K.; Moore, M.; Finlay, C.; Levine, A.J. Gain of function mutations in p53. Nat. Genet. 1993, 4, 42-46. [CrossRef]

15. Olive, K.P.; Tuveson, D.A.; Ruhe, Z.C.; Yin, B.; Willis, N.A.; Bronson, R.T.; Crowley, D.; Jacks, T. Mutant p53 gain of function in two mouse models of Li-Fraumeni syndrome. Cell 2004, 119, 847-860. [CrossRef]

16. Hingorani, S.R.; Wang, L.; Multani, A.S.; Combs, C.; Deramaudt, T.B.; Hruban, R.H.; Rustgi, A.K.; Chang, S.; Tuveson, D.A. Trp53R172H and KrasG12D cooperate to promote chromosomal instability and widely metastatic pancreatic ductal adenocarcinoma in mice. Cancer Cell 2005, 7, 469-483. [CrossRef] [PubMed]

17. Liu, D.P.; Song, H.; Xu, Y. A common gain of function of p53 cancer mutants in inducing genetic instability. Oncogene 2010, 29, 949-956. [CrossRef]

18. Scian, M.J.; Stagliano, K.E.; Ellis, M.A.; Hassan, S.; Bowman, M.; Miles, M.F.; Deb, S.P.; Deb, S. Modulation of gene expression by tumor-derived p53 mutants. Cancer Res. 2004, 64, 7447-7454. [CrossRef] [PubMed]

19. Mizuarai, S.; Yamanaka, K.; Kotani, H. Mutant p53 induces the GEF-H1 oncogene, a guanine nucleotide exchange factor-H1 for RhoA, resulting in accelerated cell proliferation in tumor cells. Cancer Res. 2006, 66, 6319-6326. [CrossRef] [PubMed]

20. Yan, W.; Chen, X. Identification of GRO1 as a critical determinant for mutant p53 gain of function. J. Biol. Chem. 2009, 284, 12178-12187. [CrossRef]

21. Zhu, J.; Sammons, M.A.; Donahue, G.; Dou, Z.; Vedadi, M.; Getlik, M.; Barsyte-Lovejoy, D.; Al-awar, R.; Katona, B.W.; Shilatifard, A.; et al. Gain-of-function p53 mutants co-opt chromatin pathways to drive cancer growth. Nature 2015, 525, 206-211. [CrossRef]

22. Di Agostino, S.; Sorrentino, G.; Ingallina, E.; Valenti, F.; Ferraiuolo, M.; Bicciato, S.; Piazza, S.; Strano, S.; Del Sal, G.; Blandino, G. YAP enhances the pro-proliferative transcriptional activity of mutant p53 proteins. EMBO Rep. 2016, 17, 188-201. [CrossRef]

23. Datta, A.; Ghatak, D.; Das, S.; Banerjee, T.; Paul, A.; Butti, R.; Gorain, M.; Ghuwalewala, S.; Roychowdhury, A.; Alam, S.K.; et al. p53 gain-of-function mutations increase Cdc7-dependent replication initiation. EMBO Rep. 2017, 18, 2030-2050. [CrossRef] [PubMed]

24. Valentino, E.; Bellazzo, A.; Di Minin, G.; Sicari, D.; Apollonio, M.; Scognamiglio, G.; Di Bonito, M.; Botti, G.; Del Sal, G.; Collavin, L. Mutant p53 potentiates the oncogenic effects of insulin by inhibiting the tumor suppressor DAB2IP. Proc. Natl. Acad. Sci. USA 2017, 114, 7623-7628. [CrossRef] [PubMed]

25. Escobar-Hoyos, L.F.; Penson, A.; Kannan, R.; Cho, H.; Pan, C.H.; Singh, R.K.; Apken, L.H.; Hobbs, G.A.; Luo, R.; Lecomte, N.; et al. Altered RNA Splicing by Mutant p53 Activates Oncogenic RAS Signaling in Pancreatic Cancer. Cancer Cell 2020, 38, 198-211.e198. [CrossRef]

26. Liu, G.; McDonnell, T.J.; Luna, R.M.D.; Kapoor, M.; Mims, B.; El-Naggar, A.K.; Lozano, G. High metastatic potential in mice inheriting a targeted p53 missense mutation. Proc. Natl. Acad. Sci. USA 2000, 97, 4174-4179. [CrossRef] [PubMed]

27. Morton, J.P.; Timpson, P.; Karim, S.A.; Ridgway, R.A.; Athineos, D.; Doyle, B.; Jamieson, N.B.; Oien, K.A.; Lowy, A.M.; Brunton, V.G.; et al. Mutant p53 drives metastasis and overcomes growth arrest/senescence in pancreatic cancer. Proc. Natl. Acad. Sci. USA 2010, 107, 246-251. [CrossRef] [PubMed]

28. Weissmueller, S.; Manchado, E.; Saborowski, M.; Morris, J.P.t.; Wagenblast, E.; Davis, C.A.; Moon, S.H.; Pfister, N.T.; Tschaharganeh, D.F.; Kitzing, T.; et al. Mutant p53 drives pancreatic cancer metastasis through cell-autonomous PDGF receptor beta signaling. Cell 2014, 157, 382-394. [CrossRef]

29. Candi, E.; Agostini, M.; Melino, G.; Bernassola, F. How the TP53 family proteins TP63 and TP73 contribute to tumorigenesis: Regulators and effectors. Hum. Mutat. 2014, 35, 702-714. [CrossRef]

30. Ferraiuolo, M.; Di Agostino, S.; Blandino, G.; Strano, S. Oncogenic Intra-p53 Family Member Interactions in Human Cancers. Front. Oncol. 2016, 6, 77. [CrossRef]

31. Zawacka-Pankau, J.E. The Undervalued Avenue to Reinstate Tumor Suppressor Functionality of the p53 Protein Family for Improved Cancer Therapy-Drug Repurposing. Cancers 2020, 12, 2717. [CrossRef] [PubMed]

32. Adorno, M.; Cordenonsi, M.; Montagner, M.; Dupont, S.; Wong, C.; Hann, B.; Solari, A.; Bobisse, S.; Rondina, M.B.; Guzzardo, V.; et al. A Mutant-p53/Smad complex opposes p63 to empower TGFbeta-induced metastasis. Cell 2009, 137, 87-98. [CrossRef]

33. Dong, P.X.; Xu, Z.J.; Jia, N.; Li, D.J.; Feng, Y.J. Elevated expression of p53 gain-of-function mutation R175H in endometrial cancer cells can increase the invasive phenotypes by activation of the EGFR/PI3K/AKT pathway. Mol. Cancer 2009, 8, 7. [CrossRef] [PubMed]

34. Muller, P.A.; Caswell, P.T.; Doyle, B.; Iwanicki, M.P.; Tan, E.H.; Karim, S.; Lukashchuk, N.; Gillespie, D.A.; Ludwig, R.L.; Gosselin, P.; et al. Mutant p53 drives invasion by promoting integrin recycling. Cell 2009, 139, 1327-1341. [CrossRef] [PubMed]

35. Zhang, S.; Wang, C.; Ma, B.; Xu, M.; Xu, S.; Liu, J.; Tian, Y.; Fu, Y.; Luo, Y. Mutant p53 Drives Cancer Metastasis via RCP-Mediated Hsp90alpha Secretion. Cell Rep. 2020, 32, 107879. [CrossRef] [PubMed] 
36. Dong, P.; Karaayvaz, M.; Jia, N.; Kaneuchi, M.; Hamada, J.; Watari, H.; Sudo, S.; Ju, J.; Sakuragi, N. Mutant p53 gain-of-function induces epithelial-mesenchymal transition through modulation of the miR-130b-ZEB1 axis. Oncogene 2013, 32, $3286-3295$. [CrossRef] [PubMed]

37. Godfrey, J.D.; Morton, J.P.; Wilczynska, A.; Sansom, O.J.; Bushell, M.D. MiR-142-3p is downregulated in aggressive p53 mutant mouse models of pancreatic ductal adenocarcinoma by hypermethylation of its locus. Cell Death Dis. 2018, 9, 14. [CrossRef]

38. Capaci, V.; Bascetta, L.; Fantuz, M.; Beznoussenko, G.V.; Sommaggio, R.; Cancila, V.; Bisso, A.; Campaner, E.; Mironov, A.A.; Wisniewski, J.R.; et al. Mutant p53 induces Golgi tubulo-vesiculation driving a prometastatic secretome. Nat. Commun. 2020, 11, 3945. [CrossRef]

39. Kogan-Sakin, I.; Tabach, Y.; Buganim, Y.; Molchadsky, A.; Solomon, H.; Madar, S.; Kamer, I.; Stambolsky, P.; Shelly, A.; Goldfinger N.; et al. Mutant p53(R175H) upregulates Twist1 expression and promotes epithelial-mesenchymal transition in immortalized prostate cells. Cell Death Differ. 2011, 18, 271-281. [CrossRef] [PubMed]

40. Yeudall, W.A.; Vaughan, C.A.; Miyazaki, H.; Ramamoorthy, M.; Choi, M.Y.; Chapman, C.G.; Wang, H.X.; Black, E.; Bulysheva, A.A.; Deb, S.P.; et al. Gain-of-function mutant p53 upregulates CXC chemokines and enhances cell migration. Carcinogenesis 2012 33, 442-451. [CrossRef]

41. Yue, X.; Zhang, C.; Zhao, Y.; Liu, J.; Lin, A.W.; Tan, V.M.; Drake, J.M.; Liu, L.; Boateng, M.N.; Li, J.; et al. Gain-of-function mutant p53 activates small GTPase Rac1 through SUMOylation to promote tumor progression. Genes Dev. 2017, 31, 1641-1654. [CrossRef]

42. Bailey, M.H.; Tokheim, C.; Porta-Pardo, E.; Sengupta, S.; Bertrand, D.; Weerasinghe, A.; Colaprico, A.; Wendl, M.C.; Kim, J.; Reardon, B.; et al. Comprehensive Characterization of Cancer Driver Genes and Mutations. Cell 2018, 173, 371-385.e318. [CrossRef]

43. Sarig, R.; Rivlin, N.; Brosh, R.; Bornstein, C.; Kamer, I.; Ezra, O.; Molchadsky, A.; Goldfinger, N.; Brenner, O.; Rotter, V. Mutant p53 facilitates somatic cell reprogramming and augments the malignant potential of reprogrammed cells. J. Exp. Med. 2010, 207, 2127-2140. [CrossRef]

44. Grespi, F.; Landre, V.; Molchadsky, A.; Di Daniele, N.; Marsella, L.T.; Melino, G.; Rotter, V. Differential regulated microRNA by wild type and mutant p53 in induced pluripotent stem cells. Cell Death Dis. 2016, 7, e2567. [CrossRef] [PubMed]

45. Lu, X.; Liu, D.P.; Xu, Y. The gain of function of p53 cancer mutant in promoting mammary tumorigenesis. Oncogene 2013, 32, 2900-2906. [CrossRef] [PubMed]

46. Escoll, M.; Gargini, R.; Cuadrado, A.; Anton, I.M.; Wandosell, F. Mutant p53 oncogenic functions in cancer stem cells are regulated by WIP through YAP/TAZ. Oncogene 2017, 36, 3515-3527. [CrossRef] [PubMed]

47. Solomon, H.; Dinowitz, N.; Pateras, I.S.; Cooks, T.; Shetzer, Y.; Molchadsky, A.; Charni, M.; Rabani, S.; Koifman, G.; Tarcic, O.; et al. Mutant p53 gain of function underlies high expression levels of colorectal cancer stem cells markers. Oncogene 2018, 37, 1669-1684. [CrossRef]

48. Polireddy, K.; Singh, K.; Pruski, M.; Jones, N.C.; Manisundaram, N.V.; Ponnela, P.; Ouellette, M.; Van Buren, G.; Younes, M.; Bynon, J.S.; et al. Mutant p53(R175H) promotes cancer initiation in the pancreas by stabilizing HSP70. Cancer Lett. 2019, 453, 122-130. [CrossRef]

49. Chen, S.; Wang, Q.; Yu, H.; Capitano, M.L.; Vemula, S.; Nabinger, S.C.; Gao, R.; Yao, C.; Kobayashi, M.; Geng, Z.; et al. Mutant p53 drives clonal hematopoiesis through modulating epigenetic pathway. Nat. Commun. 2019, 10, 5649. [CrossRef]

50. Jiang, F.Z.; He, Y.Y.; Wang, H.H.; Zhang, H.L.; Zhang, J.; Yan, X.F.; Wang, X.J.; Che, Q.; Ke, J.Q.; Chen, Z.; et al. Mutant p53 induces EZH2 expression and promotes epithelial-mesenchymal transition by disrupting p68-Drosha complex assembly and attenuating miR-26a processing. Oncotarget 2015, 6, 44660-44674. [CrossRef] [PubMed]

51. Kadosh, E.; Snir-Alkalay, I.; Venkatachalam, A.; May, S.; Lasry, A.; Elyada, E.; Zinger, A.; Shaham, M.; Vaalani, G.; Mernberger, M.; et al. The gut microbiome switches mutant p53 from tumour-suppressive to oncogenic. Nature 2020, 586, 133-138. [CrossRef] [PubMed]

52. Brabletz, T.; Jung, A.; Spaderna, S.; Hlubek, F.; Kirchner, T. Opinion: Migrating cancer stem cells - an integrated concept of malignant tumour progression. Nat. Rev. Cancer 2005, 5, 744-749. [CrossRef]

53. Donnenberg, V.S.; Donnenberg, A.D. Multiple drug resistance in cancer revisited: The cancer stem cell hypothesis. J. Clin. Pharmacol. 2005, 45, 872-877. [CrossRef] [PubMed]

54. Singh, A.; Settleman, J. EMT, cancer stem cells and drug resistance: An emerging axis of evil in the war on cancer. Oncogene 2010, 29, 4741-4751. [CrossRef]

55. Zhao, Y.; Bao, Q.; Renner, A.; Camaj, P.; Eichhorn, M.; Ischenko, I.; Angele, M.; Kleespies, A.; Jauch, K.W.; Bruns, C. Cancer stem cells and angiogenesis. Int. J. Dev. Biol. 2011, 55, 477-482. [CrossRef]

56. Sancho, P.; Barneda, D.; Heeschen, C. Hallmarks of cancer stem cell metabolism. Br. J. Cancer 2016, 114, 1305-1312. [CrossRef] [PubMed]

57. Huang, C.Y.; Ju, D.T.; Chang, C.F.; Muralidhar Reddy, P.; Velmurugan, B.K. A review on the effects of current chemotherapy drugs and natural agents in treating non-small cell lung cancer. Biomedicine 2017, 7, 23. [CrossRef]

58. Shigdar, S.; Li, Y.; Bhattacharya, S.; O'Connor, M.; Pu, C.; Lin, J.; Wang, T.; Xiang, D.; Kong, L.; Wei, M.Q.; et al. Inflammation and cancer stem cells. Cancer Lett. 2014, 345, 271-278. [CrossRef]

59. Scian, M.J.; Stagliano, K.E.R.; Anderson, M.A.E.; Hassan, S.; Bowman, M.; Miles, M.F.; Deb, S.P.; Deb, S. Tumor-derived p53 mutants induce NF-kappa B2 gene expression. Mol. Cell. Biol. 2005, 25, 10097-10110. [CrossRef] 
60. Donzelli, S.; Fontemaggi, G.; Fazi, F.; Di Agostino, S.; Padula, F.; Biagioni, F.; Muti, P.; Strano, S.; Blandino, G. MicroRNA-128-2 targets the transcriptional repressor E2F5 enhancing mutant p53 gain of function. Cell Death Differ. 2012, 19, 1038-1048. [CrossRef]

61. Ali, A.; Wang, Z.; Fu, J.; Ji, L.; Liu, J.; Li, L.; Wang, H.; Chen, J.; Caulin, C.; Myers, J.N.; et al. Differential regulation of the REGgamma-proteasome pathway by p53/TGF-beta signalling and mutant p53 in cancer cells. Nat. Commun. $2013,4,2667$. [CrossRef]

62. Kolukula, V.K.; Sahu, G.; Wellstein, A.; Rodriguez, O.C.; Preet, A.; Iacobazzi, V.; D’Orazi, G.; Albanese, C.; Palmieri, F.; Avantaggiati, M.L. SLC25A1, or CIC, is a novel transcriptional target of mutant p53 and a negative tumor prognostic marker. Oncotarget 2014, 5, 1212-1225. [CrossRef]

63. Alam, S.K.; Yadav, V.K.; Bajaj, S.; Datta, A.; Dutta, S.K.; Bhattacharyya, M.; Bhattacharya, S.; Debnath, S.; Roy, S.; Boardman, L.A.; et al. DNA damage-induced ephrin-B2 reverse signaling promotes chemoresistance and drives EMT in colorectal carcinoma harboring mutant p53. Cell Death Differ. 2016, 23, 707-722. [CrossRef] [PubMed]

64. Fontemaggi, G.; Dell'Orso, S.; Trisciuoglio, D.; Shay, T.; Melucci, E.; Fazi, F.; Terrenato, I.; Mottolese, M.; Muti, P.; Domany, E.; et al. The execution of the transcriptional axis mutant p53, E2F1 and ID4 promotes tumor neo-angiogenesis. Nat. Struct. Mol. Biol. 2009, 16, 1086-1093. [CrossRef]

65. Karin, M. Nuclear factor-kappaB in cancer development and progression. Nature 2006, 441, 431-436. [CrossRef]

66. Cooks, T.; Pateras, I.S.; Tarcic, O.; Solomon, H.; Schetter, A.J.; Wilder, S.; Lozano, G.; Pikarsky, E.; Forshew, T.; Rosenfeld, N.; et al. Mutant p53 prolongs NF-kappaB activation and promotes chronic inflammation and inflammation-associated colorectal cancer. Cancer Cell 2013, 23, 634-646. [CrossRef]

67. Ubertini, V.; Norelli, G.; D’Arcangelo, D.; Gurtner, A.; Cesareo, E.; Baldari, S.; Gentileschi, M.P.; Piaggio, G.; Nistico, P.; Soddu, S.; et al. Mutant p53 gains new function in promoting inflammatory signals by repression of the secreted interleukin-1 receptor antagonist. Oncogene 2015, 34, 2493-2504. [CrossRef] [PubMed]

68. Zhang, C.; Liu, J.; Liang, Y.; Wu, R.; Zhao, Y.; Hong, X.; Lin, M.; Yu, H.; Liu, L.; Levine, A.J.; et al. Tumour-associated mutant p53 drives the Warburg effect. Nat. Commun. 2013, 4, 2935. [CrossRef] [PubMed]

69. Zhou, G.; Wang, J.; Zhao, M.; Xie, T.X.; Tanaka, N.; Sano, D.; Patel, A.A.; Ward, A.M.; Sandulache, V.C.; Jasser, S.A.; et al. Gain-of-function mutant p53 promotes cell growth and cancer cell metabolism via inhibition of AMPK activation. Mol. Cell 2014, 54, 960-974. [CrossRef] [PubMed]

70. Bykov, V.J.; Issaeva, N.; Shilov, A.; Hultcrantz, M.; Pugacheva, E.; Chumakov, P.; Bergman, J.; Wiman, K.G.; Selivanova, G. Restoration of the tumor suppressor function to mutant p53 by a low-molecular-weight compound. Nat. Med. 2002, 8, 282-288. [CrossRef]

71. Bykov, V.J.; Zache, N.; Stridh, H.; Westman, J.; Bergman, J.; Selivanova, G.; Wiman, K.G. PRIMA-1(MET) synergizes with cisplatin to induce tumor cell apoptosis. Oncogene 2005, 24, 3484-3491. [CrossRef]

72. Bykov, V.J.; Issaeva, N.; Zache, N.; Shilov, A.; Hultcrantz, M.; Bergman, J.; Selivanova, G.; Wiman, K.G. Reactivation of mutant p53 and induction of apoptosis in human tumor cells by maleimide analogs. J. Biol. Chem. 2005, 280, 30384-30391. [CrossRef] [PubMed]

73. Zache, N.; Lambert, J.M.; Rokaeus, N.; Shen, J.; Hainaut, P.; Bergman, J.; Wiman, K.G.; Bykov, V.J. Mutant p53 targeting by the low molecular weight compound STIMA-1. Mol. Oncol. 2008, 2, 70-80. [CrossRef]

74. Wassman, C.D.; Baronio, R.; Demir, O.; Wallentine, B.D.; Chen, C.K.; Hall, L.V.; Salehi, F.; Lin, D.W.; Chung, B.P.; Hatfield, G.W.; et al. Computational identification of a transiently open L1/S3 pocket for reactivation of mutant p53. Nat. Commun. 2013, 4, 1407. [CrossRef]

75. Punganuru, S.R.; Madala, H.R.; Venugopal, S.N.; Samala, R.; Mikelis, C.; Srivenugopal, K.S. Design and synthesis of a C7-aryl piperlongumine derivative with potent antimicrotubule and mutant p53-reactivating properties. Eur. J. Med. Chem. 2016, 107, 233-244. [CrossRef]

76. Chen, S.; Wu, J.L.; Liang, Y.; Tang, Y.G.; Song, H.X.; Wu, L.L.; Xing, Y.F.; Yan, N.; Li, Y.T.; Wang, Z.Y.; et al. Arsenic Trioxide Rescues Structural p53 Mutations through a Cryptic Allosteric Site. Cancer Cell 2021, 39, 225-239.e228. [CrossRef] [PubMed]

77. Yu, X.; Vazquez, A.; Levine, A.J.; Carpizo, D.R. Allele-specific p53 mutant reactivation. Cancer Cell 2012, 21, 614-625. [CrossRef] [PubMed]

78. Soragni, A.; Janzen, D.M.; Johnson, L.M.; Lindgren, A.G.; Nguyen, A.T.Q.; Tiourin, E.; Soriaga, A.B.; Lu, J.; Jiang, L.; Faull, K.F.; et al. A Designed Inhibitor of p53 Aggregation Rescues p53 Tumor Suppression in Ovarian Carcinomas. Cancer Cell 2016, 29, 90-103. [CrossRef]

79. Parrales, A.; Ranjan, A.; Iyer, S.V.; Padhye, S.; Weir, S.J.; Roy, A.; Iwakuma, T. DNAJA1 controls the fate of misfolded mutant p53 through the mevalonate pathway. Nat. Cell Biol. 2016, 18, 1233-1243. [CrossRef] [PubMed]

80. Ingallina, E.; Sorrentino, G.; Bertolio, R.; Lisek, K.; Zannini, A.; Azzolin, L.; Severino, L.U.; Scaini, D.; Mano, M.; Mantovani, F.; et al. Mechanical cues control mutant p53 stability through a mevalonate-RhoA axis. Nat. Cell. Biol. 2018, 20, 28-35. [CrossRef]

81. Li, D.; Marchenko, N.D.; Moll, U.M. SAHA shows preferential cytotoxicity in mutant p53 cancer cells by destabilizing mutant p53 through inhibition of the HDAC6-Hsp90 chaperone axis. Cell Death Differ. 2011, 18, 1904-1913. [CrossRef] [PubMed]

82. Alexandrova, E.M.; Yallowitz, A.R.; Li, D.; Xu, S.; Schulz, R.; Proia, D.A.; Lozano, G.; Dobbelstein, M.; Moll, U.M. Improving survival by exploiting tumour dependence on stabilized mutant p53 for treatment. Nature 2015, 523, 352-356. [CrossRef] [PubMed] 
83. Hsiue, E.H.C.; Wright, K.M.; Douglass, J.; Hwang, M.S.; Mog, B.J.; Pearlman, A.H.; Paul, S.; DiNapoli, S.R.; Konig, M.F.; Wang, Q.; et al. Targeting a neoantigen derived from a common TP53 mutation. Science 2021, 371, eabc8697. [CrossRef] [PubMed]

84. Ang, H.C.; Joerger, A.C.; Mayer, S.; Fersht, A.R. Effects of common cancer mutations on stability and DNA binding of full-length p53 compared with isolated core domains. J. Biol. Chem. 2006, 281, 21934-21941. [CrossRef]

85. Lambert, J.M.; Gorzov, P.; Veprintsev, D.B.; Soderqvist, M.; Segerback, D.; Bergman, J.; Fersht, A.R.; Hainaut, P.; Wiman, K.G.; Bykov, V.J. PRIMA-1 reactivates mutant p53 by covalent binding to the core domain. Cancer Cell 2009, 15, 376-388. [CrossRef]

86. Peng, X.; Zhang, M.Q.; Conserva, F.; Hosny, G.; Selivanova, G.; Bykov, V.J.; Arner, E.S.; Wiman, K.G. APR-246/PRIMA-1MET inhibits thioredoxin reductase 1 and converts the enzyme to a dedicated NADPH oxidase. Cell Death Dis. 2013, 4, e881. [CrossRef]

87. Cordani, M.; Butera, G.; Pacchiana, R.; Masetto, F.; Mullappilly, N.; Riganti, C.; Donadelli, M. Mutant p53-Associated Molecular Mechanisms of ROS Regulation in Cancer Cells. Biomolecules 2020, 10, 361. [CrossRef]

88. Cluzeau, T.; Sebert, M.; Rahme, R.; Cuzzubbo, S.; Lehmann-Che, J.; Madelaine, I.; Peterlin, P.; Beve, B.; Attalah, H.; Chermat, F.; et al. Eprenetapopt Plus Azacitidine in TP53-Mutated Myelodysplastic Syndromes and Acute Myeloid Leukemia: A Phase II Study by the Groupe Francophone des Myelodysplasies (GFM). J. Clin. Oncol. 2021, 39, 1575-1583. [CrossRef]

89. Sallman, D.A.; DeZern, A.E.; Garcia-Manero, G.; Steensma, D.P.; Roboz, G.J.; Sekeres, M.A.; Cluzeau, T.; Sweet, K.L.; McLemore, A.; McGraw, K.L.; et al. Eprenetapopt (APR-246) and Azacitidine in TP53-Mutant Myelodysplastic Syndromes. J. Clin. Oncol. 2021, 39, 1584-1594. [CrossRef]

90. Joerger, A.C.; Fersht, A.R. Structure-function-rescue: The diverse nature of common p53 cancer mutants. Oncogene 2007, 26, 2226-2242. [CrossRef] [PubMed]

91. Salim, K.Y.; Maleki Vareki, S.; Danter, W.R.; Koropatnick, J. COTI-2, a novel small molecule that is active against multiple human cancer cell lines in vitro and in vivo. Oncotarget 2016, 7, 41363-41379. [CrossRef]

92. King, F.W.; Wawrzynow, A.; Hohfeld, J.; Zylicz, M. Co-chaperones Bag-1, Hop and Hsp40 regulate Hsc70 and Hsp90 interactions with wild-type or mutant p53. EMBO J. 2001, 20, 6297-6305. [CrossRef]

93. Hiraki, M.; Hwang, S.Y.; Cao, S.G.; Ramadhar, T.R.; Byun, S.; Yoon, K.W.; Lee, J.H.; Chu, K.; Gurkar, A.U.; Kolev, V.; et al. Small-Molecule Reactivation of Mutant p53 to Wild-Type-like p53 through the p53-Hsp40 Regulatory Axis. Chem. Biol. 2015, 22, 1206-1216. [CrossRef]

94. Hwang, L.A.; Phang, B.H.; Liew, O.W.; Iqbal, J.; Koh, X.H.; Koh, X.Y.; Othman, R.; Xue, Y.Z.; Richards, A.M.; Lane, D.P.; et al. Monoclonal Antibodies against Specific p53 Hotspot Mutants as Potential Tools for Precision Medicine. Cell Rep. 2018, 22, $299-312$. [CrossRef] [PubMed]

95. Torikai, H.; Akatsuka, Y.; Miyauchi, H.; Terakura, S.; Onizuka, M.; Tsujimura, K.; Miyamura, K.; Morishima, Y.; Kodera, Y.; Kuzushima, K.; et al. The HLA-A*0201-restricted minor histocompatibility antigen HA-1H peptide can also be presented by another HLA-A2 subtype, A*0206. Bone Marrow Transpl. 2007, 40, 165-174. [CrossRef] [PubMed]

96. Lo, W.; Parkhurst, M.; Robbins, P.F.; Tran, E.; Lu, Y.C.; Jia, L.; Gartner, J.J.; Pasetto, A.; Deniger, D.; Malekzadeh, P.; et al. Immunologic Recognition of a Shared p53 Mutated Neoantigen in a Patient with Metastatic Colorectal Cancer. Cancer Immunol. Res. 2019, 7, 534-543. [CrossRef] [PubMed]

97. Malekzadeh, P.; Pasetto, A.; Robbins, P.F.; Parkhurst, M.R.; Paria, B.C.; Jia, L.; Gartner, J.J.; Hill, V.; Yu, Z.; Restifo, N.P.; et al. Neoantigen screening identifies broad TP53 mutant immunogenicity in patients with epithelial cancers. J. Clin. Investig. 2019, 129, 1109-1114. [CrossRef]

98. Malekzadeh, P.; Yossef, R.; Cafri, G.; Paria, B.C.; Lowery, F.J.; Jafferji, M.; Good, M.L.; Sachs, A.; Copeland, A.; Kim, S.P.; et al. Antigen Experienced T Cells from Peripheral Blood Recognize p53 Neoantigens. Clin. Cancer Res. 2020, 26, 1267-1276. [CrossRef]

99. Wu, D.C.; Gallagher, D.T.; Gowthaman, R.; Pierce, B.G.; Mariuzza, R.A. Structural basis for oligoclonal T cell recognition of a shared p53 cancer neoantigen. Nat. Commun. 2020, 11, 2908. [CrossRef]

100. Mantovani, F.; Collavin, L.; Del Sal, G. Mutant p53 as a guardian of the cancer cell. Cell Death Differ. 2019, 26, 199-212. [CrossRef] 